\title{
Characterization of a novel type III alcohol dehydrogenase from Thermococcus
}

\section{barophilus Ch5}

\author{
Likui Zhang ${ }^{1,2 \#}$, Donghao Jiang ${ }^{2}$, Yuting $\mathrm{Li}^{2}$, Leilei $\mathrm{Wu}^{2}$, Qing Liu ${ }^{2}$, Kunming Dong ${ }^{2}$ \\ and Philippe Oger ${ }^{3 \#}$
}

${ }^{1}$ Guangling College, Yangzhou University, China

${ }^{2}$ College of Environmental Science and Engineering, Marine Science \& Technology Institute, Yangzhou University, China

${ }^{3}$ Univ Lyon, INSA de Lyon, CNRS UMR 5240, Villeurbanne, France

${ }^{\#}$ Corresponding author: Dr. Likui Zhang

Tel: $+86-514-89795882$

Fax: $+86-514-87357891$

E-mail address: 1kzhang@yzu.edu.cn

Corresponding author: Prof. Philippe Oger

E-mail address: philippe.oger@insa-lyon.fr 


\begin{abstract}
The genome of the hyperthermophilic and piezophilic euryarchaeaon Thermococcus barophilus Ch5 encodes three putative alcohol dehydrogenases (Tba ADHs). Herein, we characterized $\mathrm{Tba} \mathrm{ADH}_{547}$ biochemically and probed its mechanism by mutational studies. Our data demonstrate that $\mathrm{Tba} \mathrm{ADH}_{547}$ can oxidize ethanol and reduce acetaldehyde at high temperature with the same optimal temperature $\left(75^{\circ} \mathrm{C}\right)$ and exhibit similar thermostablilty for oxidization and reduction reactions. However, $\mathrm{Tba}_{\mathrm{ADH}} \mathrm{AD}_{57}$ has different optimal $\mathrm{pH}$ for oxidation and reduction: 8.5 for oxidation and 7.0 for reduction. $\mathrm{Tba}^{\mathrm{ADH}} 547$ is dependent on a divalent ion for its oxidation activity, among which $\mathrm{Mn}^{2+}$ is optimal. However, Tba $\mathrm{ADH}_{547}$ displays about $20 \%$ reduction activity without a divalent ion, and the maximal activity with $\mathrm{Fe}^{2+}$. Furthermore, $\mathrm{Tba} \mathrm{ADH}_{547}$ showcases a strong substrate preference for 1-butanol and 1-hexanol over ethanol and other alcohols. Similarly, Tba $\mathrm{ADH}_{547}$ prefers butylaldehyde to acetaldehyde as its reduction substrate. Mutational studies showed that the mutations of residues D195, H199, H262 and H234 to Ala result in the significant activity loss of Tba $\mathrm{ADH}_{547}$, suggesting that residues D195, H199, H262 and $\mathrm{H} 234$ are responsible for catalysis. Overall, $\mathrm{Tba} \mathrm{ADH}_{547}$ is a thermoactive $\mathrm{ADH}$ with novel biochemical characteristics, thereby allowing this enzyme to be a potential biocatalyst.
\end{abstract}

Keywords: Hyperthermophilic Archaea; Alcohol dehydrogenase; Biochemical characteristics 


\section{Introduction}

Alcohol dehydrogenases (ADHs), which are members of the oxidoreductase family, are able to catalyze the cofactor-dependent oxidation of ethanol and other alcohols to produce the corresponding aldehydes and ketones [1]. Thus, ADHs play important roles in the detoxification and metabolism of primary and secondary alcohols. Based on their cofactor requirements, ADHs are classified into four types: nicotinamide adenine dinucleotide (NAD) dependent $\mathrm{ADH}$; pyrroloquinoline quinone (PQQ) -dependent ADH; heme or cofactor F420 -dependent ADH; flavine adenine dinucleotide -(FAD) dependent $\mathrm{ADH}$ [2]. In addition, NAD-dependent ADHs are further subdivided into three types depending on the alcohols metabolized: short-chain ADHs exemplified by the drosophila ADH [3] (type I), medium-chain or zinc ADHs (type II or Zn-ADH) exemplified by the horse liver ADH [4], and long-chain or iron ADHs (type III or Fe-ADH) exemplified by the Zymomonas ADH2 $[5,6]$. These three families display low similarity and arose independently throughout evolution, suggesting that these ADHs harbor different structures and mechanisms of reaction.

Several type III ADHs have been biochemically characterized since a type III ADH was first reported from Zymomonas mobilis, including Saccharomyces cerevisiae ADH4 [7], Escherichia coli L-1,2-propanediol oxidoreductase [8], Clostridium acetobutylicum ADH1 [9], C. acetobutylicum butanol dehydrogenases [10], and Bacillus methanolicus methanol dehydrogenase [11], and a human iron-activated $\mathrm{ADH}$ [12]. Crystal structures of the type III ADHs from bacteria and 
archaea show that they possesses a very highly conserved catalytic cleft where $\mathrm{Fe}^{2+}$ ion is coordinated with three His residues and one Asp residue [13-16]. Currently, several type III ADHs from hyperthermophilic Thermococus have been reported since the first type III ADH was characterized from Thermococcus litoralis [17], including Thermococcus strain ES-1 [18-19], Thermococcus strain AN1 [20], Thermococcus hydrothermalis [21], and Thermococcus thioreducens [15] and Pyrococcus furiosus [22]. All these reported type III ADHs from HA have one common characteristic: high thermostability, which is distinct from other ADHs from mesophiles. Although several ADHs from HA have been found, thermostable ADHs are still in demand due to unique characteristics, demonstrating a variety of substrate specificities and physiological functions.

Thermococcus barophilus $\mathrm{Ch} 5$, which was isolated from a deep-sea hydrothermal field of the Mid-Atlantic Ridge (Logachev field chimney, 3,020 m depth), is a thermo-piezophilic euryarchaeon, growing optimally at $88^{\circ} \mathrm{C}$ under $40 \mathrm{MPa}$ of hydrostatic pressure [23]. The genome of $T$. barophilus $\mathrm{Ch} 5$ encodes 2,679 proteins, two thirds of which have no associated functions [24]. Furthermore, several thermostable enzymes from T. barophilus $\mathrm{Ch} 5$ have been characterized [25-29] and have been shown to have distinct characteristics from other homologues found in other extremophilic archaeal models. Thus, $T$. barophilus $\mathrm{Ch} 5$ is an important model for studying structural and function relationship of thermostable proteins or enzymes present in hyperthermophilies as well as a great untapped source of novel extreme thermophilic enzymes for industrial processes. 
Three putative alcohol dehydrogenases (Tba ADHs) are encoded in the genome of T. barophilus Ch5, including one short-chain ADH (GenBank: ALM74123) and two putative type III ADHs (GenBank: ALM74514 and ALM74601). Interestingly, these two putative Fe-ADHs from T. barophilus $\mathrm{Ch} 5$ have only $26 \%$ similarity in amino acid compositions, suggesting that they might harbor distinct characteristics. Currently, no ADHs from T. barophilus $\mathrm{Ch} 5$ has been biochemically characterized. In this work, we report the cloning, expression, biochemical characterization and mutational studies of the recombinant $\mathrm{Tba} \mathrm{ADH}_{547}$ encoded by gene TBCH5v1_0547 (Genbank: ALM74514) and is conserved in all Thermococcales species, suggesting that this $\mathrm{ADH}$ might be a putative type III alcohol dehydrogenase with novel characterization.

\section{Materials and methods}

\subsection{Materials}

The pET-30a $(+)$ vector was purchased from Novagen (Merck, Darmstadt, Germany). Plasmid Extraction Kit, PCR Cycle Pure Kit, and Gel Extraction Kit were purchased from Omega (Guangzhou, China). Escherichia coli DH5 $\alpha$ cells and E. coli BL21 (DE3) cells were purchased from Transgene (Beijing, China); dNTPs, T4 DNA ligase, NdeI, XhoI, and Pfu DNA polymerase were purchased from Thermo Scientific (Waltham, MA). Chemicals were purchased from Amresco (WA, USA).

\subsection{Phylogenetic analyses}

The genes coding for $\mathrm{Tba} \mathrm{ADH}_{547}$ and $\mathrm{Tba} \mathrm{ADH}_{641}$ were used to identify their homologues in all Thermococcales species which genomes are sequenced. ADH 
sequences were aligned in Seaview with Muscle [30]. Conserved sites were selected with GBlocks. PhyML v3.696 was employed to construct a maximum likelihood unrooted phylogenetic tree. Bootstrapping was performed with 1000 replicates. The sequence accession numbers for each individual protein is labeled in the tree. The tree was inferred with PhyML. The scale bar represents the average number of substitutions per site. Numbers at branches represent bootstrap values (1000 replicates, values $>50 \%$ are shown).

\subsection{Sequence alignment}

The target $\mathrm{ADH}$ sequences from archaea, bacteria and eukaryotes were retrieved from NCBI. The sequences were aligned by DNAMAN software version 6 . The alignment figure was output with a graphic file.

\subsection{Cloning of the gene encoding Tba $A D H_{547}$}

We amplified the TBCH5v1_0547 gene encoding a putative type III alcohol dehydrogenase using the $T$. barophilus $\mathrm{Ch} 5$ genomic DNA as a template and Pfu DNA polymerase in the presence of the forward primer and the reverse primer. The sequences of these two primers are listed in Table 1. The amplified PCR product and the pET-30a $(+)$ vector were digested by $N d e \mathrm{I}$ and $X h o \mathrm{I}$, and the cleaved DNA fragments were ligated by T4 DNA ligase to yield the recombinant plasmid pET30a $(+)-T b a \mathrm{ADH}_{547}$, and transformed into E. coli DH5a cells. After sequence verification, the recombinant plasmid $\mathrm{pET30a}(+)-\mathrm{Tba} \mathrm{ADH}_{547}$ was transformed into $E$. coli BL21 (DE3) cells for expression of the $\mathrm{Tba} \mathrm{ADH}_{547}$ protein harboring a $6 \mathrm{x}$ His-tag in its C-terminus. 


\subsection{Overexpression and purification of $\mathrm{Tba}^{\mathrm{ADH}} \mathrm{H}_{547}$}

For the $\mathrm{Tba} \mathrm{ADH}_{547}$ protein expression, the expression strain E. coli BL21 (DE3) harboring the pET30a(+)-Tba $\mathrm{ADH}_{547}$ plasmid was cultured at $37^{\circ} \mathrm{C}$ in $\mathrm{LB}$ medium containing $10 \mu \mathrm{g} / \mathrm{mL}$ kanamycin until the $\mathrm{OD}_{600}$ reached 0.6 . Then, the expression of the Tba $\mathrm{ADH}_{547}$ gene was induced by addition of isopropyl thiogalactoside (IPTG, 0.1 $\mathrm{mM})$. Expression was performed for 12 hat room temperature.

Cells were harvested by centrifugation $(5,000 \mathrm{~g})$ at room temperature. The collected pellet was resuspended in Ni column buffer A containing $20 \mathrm{mM}$ Tris- $\mathrm{HCl}$ (pH 8.0), $1 \mathrm{mM}$ dithiothreitol (DTT), $500 \mathrm{mM} \mathrm{NaCl}, 50 \mathrm{mM}$ imidazole and $10 \%$ glycerol. Cells were disrupted by ultrasonication at $4^{\circ} \mathrm{C}$. Cell debris was removed by centrifugation $(16,000 \mathrm{~g})$ at $4^{\circ} \mathrm{C}$. The collected supernatant was heated at $70^{\circ} \mathrm{C}$ for 20 min to inactivate the $E$. coli proteins. After centrifugation at $16,000 \mathrm{~g}$ and $4^{\circ} \mathrm{C}$, the resulting supernatant was loaded onto a HisTrap FF column (GE Healthcare, Uppsala, Sweden). The Tba $\mathrm{ADH}_{547}$ protein was eluted with $\mathrm{NCG}^{\mathrm{TM}}$ Chromatography System (Bio-Rad, Hercules, CA, USA) by a linear gradient of 50-500 mM imidazole with a Ni column buffer B containing 20 mM Tris-HCl (pH 8.0), 1 mM DTT, 500 mM NaCl, $500 \mathrm{mM}$ imidazole and $10 \%$ glycerol. The collected fractions containing the His-tagged Tba $\mathrm{ADH}_{547}$ protein were analyzed by migration on a $10 \%$ SDS-PAGE. The purified $\mathrm{Tba} \mathrm{ADH}_{547}$ protein fractions were combined and dialyzed against a storage buffer containing $50 \mathrm{mM}$ Tris- $\mathrm{HCl}(\mathrm{pH} 8.0), 1 \mathrm{mM}$ DTT, 50\% glycerol and 50 $\mathrm{mM} \mathrm{NaCl}$, and stored at $-80^{\circ} \mathrm{C}$. The $\mathrm{Tba} \mathrm{ADH}_{547}$ protein concentration was determined by measuring the absorbance at $280 \mathrm{~nm}$. The theoretical molar extinction 
coefficient of $\mathrm{TbaADH}_{547}$ protein is predicted to be $33,350 \mathrm{M}^{-1} \mathrm{~cm}^{-1}$.

\subsection{Construction, overexpression, and purification of the Tba $\mathrm{ADH} 547$ mutants}

Following the manufacturer's instructions, the $\mathrm{Tba}^{\mathrm{ADH}} \mathrm{AD}_{54}$ mutants were constructed by Site-Directed Mutagenesis Kit (Transgene, China) using the wild-type Tba $\mathrm{ADH}_{547}$ gene as a template. The sequences of the mutagenic primers are listed in Table 1. The D195A, H199A, H262A, H266A, and H274A mutant plasmids were verified by sequencing, and the mutant proteins were overexpressed, purified and quantified as described for the wild-type protein.

\subsection{Enzymatic assays of Tba $A D H_{547}$}

The standard $\mathrm{Tba} \mathrm{ADH}_{547}$ enzymatic assay was performed in a total volume of 3 $\mathrm{ml}$ containing $100 \mathrm{mM}$ Tris- $\mathrm{HCl}(\mathrm{pH} 8.5), 0.67 \mathrm{mM} \mathrm{NAD}^{+}, 0.1 \mathrm{mM} \mathrm{MgCl} 2,0.46 \mathrm{M}$ ethanol and $500 \mathrm{nM} \mathrm{Tba} \mathrm{ADH}_{547}$ at $75^{\circ} \mathrm{C}$ for 30 min and was terminated by placing samples on ice. Alternatively, the standard reaction for the reductive reaction in a total volume of $3 \mathrm{ml}$ including $100 \mathrm{mM}$ Tris- $\mathrm{HCl}(\mathrm{pH} 8.5), 0.3 \mathrm{mM} \mathrm{NADH}, 0.46 \mathrm{M}$ acetaldehyde, $0.1 \mathrm{mM} \mathrm{FeSO}_{4}$, and $500 \mathrm{nM} \mathrm{Tba} \mathrm{ADH}_{547}$ was conducted at $75^{\circ} \mathrm{C}$ for 30 min and were terminated by placing samples on ice. Tba $\mathrm{ADH}_{547}$ activity was determined spectrophotometrically at $340 \mathrm{~nm}$ by measuring the amount of NADH produced or reduced. The extinction coefficient $\left(\varepsilon_{340}\right)$ was $6,220 \mathrm{M}^{-1} \mathrm{~cm}^{-1}$. All reactions were performed in triplicate and the average values were reported. One unit of enzyme was defined as the amount of enzyme producing or reducing $1 \mu \mathrm{mol}$ of NADH per min.

The optimal reaction temperature of the $\mathrm{Tba}^{\mathrm{ADH}} 547$ activity was investigated in 
the standard conditions but varying temperature in a $40^{\circ} \mathrm{C}$ to $100^{\circ} \mathrm{C}$ range for oxidation and in a $40^{\circ} \mathrm{C}$ to $80^{\circ} \mathrm{C}$ for reduction. The optimal $\mathrm{pH}$ of the $\mathrm{Tba} \mathrm{ADH}_{547}$ activity was determined at $75^{\circ} \mathrm{C}$ varying the $\mathrm{pH}$ of the reactions between 6.5 and 10 for oxidation and between 6.0 and 8.0 for reduction. The varied pHs were adjusted with five different buffers (all at $20 \mathrm{mM}$ concentrations): sodium phosphate- $\mathrm{NaOH}$ (pH 6.0, $\mathrm{pH} 6.5$ and $\mathrm{pH} 7.0)$, Tris- $\mathrm{HCl}(\mathrm{pH} 7.5, \mathrm{pH} 8.0$, and $\mathrm{pH} 8.5$ at the desired temperature), and $\mathrm{Gly}-\mathrm{NaOH}(\mathrm{pH} 9.0, \mathrm{pH} 9.5$ and $\mathrm{pH}$ 10.0). The requirement for a divalent ion for the activity of $\mathrm{Tba}^{\mathrm{ADH}} \mathrm{A}_{57}$ was assayed in presence of $10 \mathrm{mM}$ EDTA or $0.1 \mathrm{mM} \mathrm{Fe}^{2+}, \mathrm{Mg}^{2+}, \mathrm{Mn}^{2+}, \mathrm{Co}^{2+}, \mathrm{Cu}^{2+}, \mathrm{Ca}^{2+}, \mathrm{Ni}^{2+}$ or $\mathrm{Zn}^{2+}$. The substrate specificity of the $\mathrm{Tba} \mathrm{ADH}_{547}$ activity was investigated with ethanol, methanol, isopentanol, isopropanol, ethylene glycol, 1-butanol, 1-hexanol or glycerol as the substrates for oxidation, and with acetone, butylaldehyde, caproaldehyde or acetaldehyde as the substrates for reduction.

\subsection{Kinetic assays of $\mathrm{Tba} \mathrm{ADH}_{547}$}

The kinetic parameters of $\mathrm{Tba}^{\mathrm{ADH}} \mathrm{D}_{547}$ were obtained by performing reactions at different ethanol concentrations ( $1 \mathrm{mM}, 5 \mathrm{mM}, 10 \mathrm{mM}, 20 \mathrm{mM}, 40 \mathrm{mM}, 80 \mathrm{mM}, 100$ $\mathrm{mM}$ and $200 \mathrm{mM})$ for oxidation and at different acetaldehyde concentrations $(1 \mathrm{mM}$, $2.5 \mathrm{mM}, 5 \mathrm{mM}, 10 \mathrm{mM}, 20 \mathrm{mM}, 40 \mathrm{mM}, 80 \mathrm{mM}$, and $100 \mathrm{mM}$ ) for reduction. The corresponding $K_{\mathrm{m}}$ and $V_{\max }$ values were calculated using the linear regression and the values given represented the calculated mean.

\subsection{Circular dichroism $(C D)$ measurements}

The wild-type (WT), D195A, H199A, H262A, H266A and H274A mutant Tba 
$\mathrm{ADH}_{547}$ proteins were dialyzed into $50 \mathrm{mM}$ PBS (phosphate-buffered saline) $\mathrm{pH} 7.5$ for $\mathrm{CD}$ analysis. The $\mathrm{CD}$ spectra were recorded at $20^{\circ} \mathrm{C}$ from $200 \mathrm{~nm}$ to $250 \mathrm{~nm}$ using a J-810 spectropolarimeter (JASCO, Japan) and a cuvette of path length $0.2 \mathrm{~cm}$. The spectra were generated with $0.2 \mathrm{mg} / \mathrm{ml} \mathrm{WT}$ and mutant $\mathrm{Tba}^{\mathrm{ADH}} \mathrm{AD}_{547}$ proteins at a scanning rate of $50 \mathrm{~nm} / \mathrm{min}$, and triplicate spectrum readings were collected per sample. The CD spectral data were reported as mean residue ellipticity [ $\theta]$ by using the program KaleidaGraph (Synergy Software).

\section{Results \\ 3.1 Tba $\mathrm{ADH}_{547}$ is a putative type III alcohol dehydrogenase}

Two putative NAD-ADHs of type III (Fe-ADH) are encoded in the genome of $T$. barophilus $\mathrm{Ch}$ 5: Tba $\mathrm{ADH}_{641}$ and $\mathrm{Tba} \mathrm{ADH}_{547}$. As shown in Fig. 1A, Tba $\mathrm{ADH}_{547}$ and Tba $\mathrm{ADH}_{641}$ are clustered in different branches. $\mathrm{Tba} \mathrm{ADH}_{547}$ is conserved in all Thermococcales species (Fig. 1B), including Thermococcus, Pyrococcus and Palaeococcus genera. Tba $\mathrm{ADH}_{547}$ is the most closely related to $\mathrm{ADH}$ from $T$. paralvinellae (Fig. 1B), and this ADH displays a relative closer relation with the $\mathrm{ADH}$ homologues from Palaeococcus than the ADH homologues from Pyrococcus in Thermocococcales. Surprisingly, $\mathrm{Tba}_{\mathrm{ADH}} \mathrm{A}_{57}$ is not conserved in other Archaea (Fig. 1B). It is only distantly related to bacterial homologues (Fig. 1B). Tba $\mathrm{ADH}_{547}$ displays $26 \sim 30 \%$ similarity with $\mathrm{Tba} \mathrm{ADH}_{641}$ and the homologues from Thermococcus strain ES-1, T. hydrothermalis, T. litoralis, Thermococcus strain AN1, Thermococcus kodakarensis (ADH2), Pyrococcus furiosus, Z. mobilis and S. cerevisiae. In contrast, $\mathrm{Tba} \mathrm{ADH}_{547}$ exhibits $71 \sim 75 \%$ similarity with the homologues 
from Thermococcus strain AN1, T. thioreducens and T. kodakarensis (ADH1), suggesting that $\mathrm{Tba} \mathrm{ADH}_{547}$ might be more similar in function to $T$. zilligii, $T$. thioreducens and T. kodakarensis (ADH1) ADHs. Thus, the low similarity of two type III ADHs from T. barophilus Ch5 suggests that they might have distinct biochemical characteristics.

As shown in Fig. 2, $\mathrm{Tba} \mathrm{ADH}_{547}$ possesses three conserved motifs: motif I (GGGS), motif II (DxxxH), and motif III (a conserved motif with three histidine residues), which are present in type III ADHs. However, the amino acid variations and three residues are missing in the highly conserved motif III in $\mathrm{Tba}^{\mathrm{ADH}} 547$ and ADHs from T. thioreducens, T. kodakarensis (ADH1) and Thermococcus strain AN1. Furthermore, thirty four residues are strictly conserved in all thirteen proteins (Fig. 2), including seven glycine residues, six proline residues, six alanine residues, four histidine residues, three aspartic acid residues, two lysine residues, two glutamic acid residues, one threonine, one leucine and one isoleucine. Overall, Tba $\mathrm{ADH}_{547}$ possesses the conserved motifs present in type III ADHs, however, displays low similarity with the homologues exemplified by $\mathrm{Tba}_{\mathrm{ADH}} \mathrm{A}_{61} \mathrm{ADH}$.

\subsection{Cloning, expression and purification of $T b a \mathrm{ADH} \mathrm{H}_{57}$ protein}

In this work, we cloned the $\mathrm{Tba} \mathrm{ADH}_{547}$ gene encoded by TBCH5v1_0547 (Genbank: ALM74514) into a pET30a(+) expression vector and overexpressed it in $E$. coli BL21 (DE3) cells. As shown in Fig. 3A, the gene encoding the Tba $\mathrm{ADH}_{547}$ protein was successfully induced after addition of IPTG and the expressed protein was recovered in the supernatant after ultrasonication disruption. After heat treatment at 
$70^{\circ} \mathrm{C}$ for $30 \mathrm{~min}$, most of $E$. coli proteins were inactivated and removed after centrifuge, however, the Tba $\mathrm{ADH}_{547}$ protein can withstand this heat treatment. Last, the recombinant $\mathrm{Tba} \mathrm{ADH}_{547}$ protein was purified to near homogeneity after Ni-column affinity purification (Fig. 3A). The purified $6 \times$ His-tagged protein displayed an approximate MW of $42 \mathrm{kDa}$ (Fig. 3A), consistent with the deduced amino acid sequence.

\subsection{Effect of temperature on Tba $\mathrm{ADH}_{547}$ activity}

Since T. barophilus Ch5 is a hyperthermophile [23], we expect its proteins or enzymes to be highly thermophilic and thermostable. We first investigated the thermophilicity of $\mathrm{Tba} \mathrm{ADH}_{547}$ by performing enzyme activity assays at varied temperatures ranging from $40^{\circ} \mathrm{C}$ to $100^{\circ} \mathrm{C}$. As shown in Fig. $3 \mathrm{~B}$, Tba $\mathrm{ADH}_{547}$ only retained about $10 \%$ and $30 \%$ relative activity at $40^{\circ} \mathrm{C}$ and $100^{\circ} \mathrm{C}$, respectively. Tba $\mathrm{ADH}_{547}$ displayed maximal activity at $75^{\circ} \mathrm{C}$, which makes it a thermophilic enzyme.

Next, we determined whether $\mathrm{Tba} \mathrm{ADH}_{547}$ has reduction activity. Using acetaldehyde as the substrate, we performed the reduction reaction catalyzed by Tba $\mathrm{ADH}_{547}$ in the presence of $\mathrm{NADH}$ at various temperatures ranging from $40^{\circ} \mathrm{C}$ to $80^{\circ} \mathrm{C}$ since NADH is unstable at temperatures higher than $80^{\circ} \mathrm{C}$. We found that $\mathrm{Tba} \mathrm{ADH}_{547}$ has the reduction activity, and also displays maximal activity for acetaldehyde reduction at $75^{\circ} \mathrm{C}$ (Fig. 3B). Thus, Tba $\mathrm{ADH}_{547}$ has the same optimal reaction temperature for both ethanol oxidation and acetaldehyde reduction under our standard reaction conditions.

\subsection{Thermostablilty of Tba $\mathrm{ADH}_{547}$}


To probe the thermostability of $\mathrm{Tba} \mathrm{ADH}_{547}$, we incubated this $\mathrm{ADH}$ at varied temperatures for different times and then used the heated enzyme to perform the ethanol oxidation and acetaldehyde reduction reactions. We selected the heated Tba $\mathrm{ADH}_{547}$ at 90,95 and $100^{\circ} \mathrm{C}$ for 30 min for analyzing its reduction activity. As shown in Fig. 4A, the reduction activity of $\mathrm{Tba}^{\mathrm{ADH}} 547$ decreased as the heating temperature increased. However, this ADH still retained 20\% reduction activity even after this $\mathrm{ADH}$ was heated at $100^{\circ} \mathrm{C}$ for $30 \mathrm{~min}$.

On the other hand, we employed the heated $\mathrm{Tba}^{\mathrm{ADH}} 547$ at $100^{\circ} \mathrm{C}$ at varied times to analyze its oxidation reaction. Compared with the control reaction without the heating treatment, the oxidation activity of $\mathrm{Tba} \mathrm{ADH}_{547}$ was lowered as the heating time extended, (Fig. 4B). However, Tba $\mathrm{ADH}_{547}$ still harbored about $20 \%$ oxidation activity after heating at $100^{\circ} \mathrm{C}$ for $30 \mathrm{~min}$, which is consistent with the observation for the reduction activity of the enzyme heated at $100^{\circ} \mathrm{C}$ for $30 \mathrm{~min}$. Overall, $\mathrm{Tba}^{\mathrm{ADH}} \mathrm{H}_{547}$ is a thermophilic and thermostable $\mathrm{ADH}$, suggesting it potential application in ethanol oxidation and acetaldehyde reduction at high temperature.

\subsection{Effect of pH on Tba ADH 547 activity}

Next, we investigated the optimal $\mathrm{pH}$ for ethanol oxidation and acetaldehyde reduction of $\mathrm{Tba} \mathrm{ADH}_{547}$. As shown in Fig. 5A, no $\mathrm{Tba} \mathrm{ADH}_{547}$ activity was observed below $\mathrm{pH} 6.5$ and only a residual activity was detected at $\mathrm{pH} 10 . \mathrm{Tba} \mathrm{ADH}_{547}$ can oxidize ethanol in the $\mathrm{pH}$ range from 7.0 to 10.0 . At $\mathrm{pH} 8.5$, $\mathrm{Tba}^{\mathrm{ADH}} \mathrm{AD}_{57}$ displayed maximal activity, suggesting that $\mathrm{pH} 8.5$ is the optimal $\mathrm{pH}$ for the reduction reaction of this ADH. 
The effect of $\mathrm{pH}$ on reduction reaction of $\mathrm{Tba}^{\mathrm{ADH}} \mathrm{H}_{57}$ was also determined using varied $\mathrm{pH}$ buffers ranging from 6.0 to 8.0 since $\mathrm{NADH}$ is unstable at above $\mathrm{pH} 8.0$ (Fig. 5A). Tba $\mathrm{ADH}_{547}$ exhibited maximal reduction activity at $\mathrm{pH} 7.0$, suggesting that its optimal reaction $\mathrm{pH}$ is 7.0 , which is lower than that of its oxidation reaction. Thus, Tba $\mathrm{ADH}_{547}$ displays distinct optimal $\mathrm{pH}$ adaptation for oxidation and reduction reactions.

\subsection{Effect of divalent ions on $\mathrm{Tba} \mathrm{ADH}_{547}$ activity}

The metal requirements of archaeal NAD-dependent ADHs are very variable, thus, we investigated the metal dependency of $\mathrm{Tba}^{\mathrm{ADH}} 547$ activity for ethanol oxidation. In the absence of the addition of a divalent ion or in the presence of $10 \mathrm{mM}$ EDTA (the latter should chelate the divalent ions eventually co-purified with the Tba $\mathrm{ADH}_{547}$ enzyme), Tba $\mathrm{ADH}_{547}$ yielded no measurable activity (Fig. 5B). The activity in $\mathrm{Tba} \mathrm{ADH}_{547}$ is restored to some extent upon addition of all the divalent ions tested. Maximum $\mathrm{Tba} \mathrm{ADH}_{547}$ activity was observed in the presence of $0.1 \mathrm{mM} \mathrm{Mn}^{2+}$. By contrast, the lowest activity of Tba $\mathrm{ADH}_{547}$ was found in the presence of $0.1 \mathrm{mM} \mathrm{Zn}^{2+}$, $\mathrm{Cu}^{2+}, \mathrm{Ca}^{2+}, \mathrm{Ni}^{2+}, \mathrm{Co}^{2+}, \mathrm{Mg}^{2+}$ or $\mathrm{Fe}^{2+}$, which stimulated $\mathrm{Tba} \mathrm{ADH}_{547}$ activity with less than $50 \%$ of that observed with $\mathrm{Mn}^{2+}$. Thus, $\mathrm{Tba}^{\mathrm{ADH}} \mathrm{AD}_{547}$ is dependent on a divalent ion for ethanol oxidation, which is sharply contrasted to the currently reported ADHs.

Compared with the oxidation reaction, Tba $\mathrm{ADH}_{547}$ displays about $30 \%$ reduction activity in the absence of divalent ion or in the presence of EDTA (Fig. 5B). Surprisingly, this $\mathrm{ADH}$ exhibits maximal reduction activity in the presence of $\mathrm{Fe}^{2+}$, suggesting that $\mathrm{Fe}^{2+}$ is the optimal divalent ion for its reduction activity, which is 
sharply contrasted with the observation that $\mathrm{Mn}^{2+}$ is the optimal ion for the oxidation activity of this ADH. Compared with the control reactions without divalent ion or without EDTA, $\mathrm{Ca}^{2+}$ slightly inhibited the reduction activity whereas $\mathrm{Cu}^{2+}, \mathrm{Mg}^{2+}$, or $\mathrm{Ni}^{2+}$ stimulated the reduction activity of this $\mathrm{ADH}$ with varied degrees. On the other hand, $\mathrm{Zn}^{2+}$ or $\mathrm{Mn}^{2+}$ enables this $\mathrm{ADH}$ to retain similar reduction activity to the control reactions. Thus, $\mathrm{Tba}_{\mathrm{ADH}} \mathrm{A}_{57}$ displays distinct divalent ion adaptation for acetaldehyde reduction.

\subsection{Substrate specificity of $\mathrm{Tba} A D \mathrm{AH}_{547}$}

We determined the substrate specificity of $\mathrm{Tba} \mathrm{ADH}_{547}$ under the optimal conditions $\left(75^{\circ} \mathrm{C}, \mathrm{pH} 8.5\right.$ and $\left.0.1 \mathrm{mM} \mathrm{Mn}^{2+}\right)$ for oxidation. Quite strikingly, we found that the recombinant $\mathrm{Tba}^{\mathrm{ADH}} 547$ exhibited the highest activity in the presence of 1-butanol or 1-hexanol and not in the presence of ethanol, suggesting that 1-butanol and 1-hexanol are more suitable substrates for this enzyme than is ethanol (Fig. 6A). Only a few other primary alcohols were possible substrates for $\mathrm{Tba}^{\mathrm{ADH}} \mathrm{H}_{547}$, including ethylene glycol ( $40 \%$ activity), isopentanol ( $25 \%$ activity), isopropanol (10\% activity) and glycerol (5\% activity). In contrast, we observed that $\mathrm{Tba}^{\mathrm{ADH}} 547$ is fully inactive on methanol. Thus, $\mathrm{Tba}^{\mathrm{ADH}} 547$ displays a preference for substrate in the order from high to low: 1-butanol $>$ 1-hexanol $>$ ethanol $>$ ethylene glycol $>$ isopentanol $>$ isopropanol $>$ glycerol. Combining all these observations, we can conclude that the optimal reaction conditions for $\mathrm{Tba}^{\mathrm{ADH}} \mathrm{D}_{547}$ activity with 1-butanol as a substrate are: $75^{\circ} \mathrm{C}, \mathrm{pH} 8.5$ and $0.1 \mathrm{mM} \mathrm{Mn}^{2+}$. Under the optimal reaction conditions, we measured the specific activity of $\mathrm{Tba}_{\mathrm{ADH}} \mathrm{A}_{57}$ to be $931 \mathrm{U} / \mathrm{mg}$ for 1-butanol oxidation. 
Next, we determined the substrate specificity of reduction reaction of Tba $\mathrm{ADH}_{547}$ using acetone, acetaldehyde, caproaldehyde and butylaldehyde as the substrates. Similar to the oxidation reaction with 1-butanol as a preference substrate, Tba $\mathrm{ADH}_{547}$ displayed higher reduction activity in the presence of butylaldehyde than in the presence of acetaldehyde (Fig. 6B), suggesting that butylaldehyde is more suitable substrate than acetaldehyde for reduction reaction of this ADH. Compared with the acetaldehyde reduction reaction, $\mathrm{Tba} \mathrm{ADH}_{547}$ retained significantly lowered reduction activity for acetone and caproaldehyde reduction, suggesting that acetone and caproaldehyde are also possible substrates for reduction activity of this ADH. Thus, the optimal reaction conditions for $\mathrm{Tba} \mathrm{ADH}_{547}$ reduction activity with butylaldehyde as a substrate are: $75^{\circ} \mathrm{C}, \mathrm{pH} 7.0$ and $0.1 \mathrm{mM} \mathrm{Fe}^{2+}$. The specific activity of $\mathrm{Tba} \mathrm{ADH}_{547}$ was measured to be $3924 \mathrm{U} / \mathrm{mg}$ for butylaldehyde reduction, suggesting that this $\mathrm{ADH}$ has a higher activity for aldehyde reduction than alcohol oxidation.

\section{$3.8 K_{m}$ and $V_{\max }$ for $T b a A D H_{547}$}

We determined the kinetic parameters of $\mathrm{Tba}^{\mathrm{ADH}} \mathrm{A}_{547}$ using the ethanol at varied concentrations ranging from $1 \mathrm{mM}$ to $200 \mathrm{mM}$ as the substrates under the optimal oxidation conditions as described above. The $K_{\mathrm{m}}$ and $V_{\max }$ values were calculated to be $92 \mathrm{mM}$ and $8 \times 10^{-3} \mathrm{mM} / \mathrm{min}$ from the fitted Lineweaver-Burk plot (Fig. 7A), respectively. Considering that $500 \mathrm{nM}$ Tba $\mathrm{ADH}_{547}$ was employed in oxidation reaction, the $K_{\text {cat }}$ was further measured to be $0.27 \mathrm{~s}^{-1}$.

Furthermore, we examined the kinetic parameters of $\mathrm{Tba}^{\mathrm{ADH}} \mathrm{AD}_{547}$ using the 
acetaldehyde at varied concentrations ranging from $1 \mathrm{mM}$ to $80 \mathrm{mM}$ as the substrates under the optimal reaction condition $\left(75^{\circ} \mathrm{C}, \mathrm{pH} 7.0\right.$ and $\left.0.1 \mathrm{mM} \mathrm{Fe}^{2+}\right)$. As shown in Fig. 7B, the $K_{\mathrm{m}}$ and $V_{\max }$ values of $\mathrm{Tba} \mathrm{ADH}_{547}$ for acetaldehyde reduction were estimated to be $34.5 \mathrm{mM}$ and $0.266 \mathrm{mM} / \mathrm{min}$ from the fitted Lineweaver-Burk plot, respectively. The corresponding $K_{\text {cat }}$ for acetaldehyde reduction was further calculated to be $69 \mathrm{~s}^{-1}$, which is about 256 -fold higher than that for ethanol oxidation. By contrast, the $K_{\mathrm{m}}$ value for acetaldehyde reduction of $\mathrm{Tba}^{\mathrm{ADH}_{547}}$ is about 2.7-fold

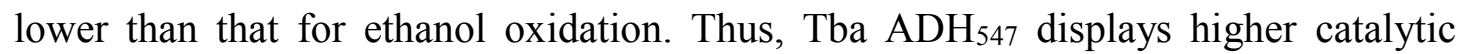
efficiency for acetaldehyde reduction than for ethanol oxidation.

\subsection{Mutational studies of Tba $\mathrm{ADH}_{547}$}

As shown in Fig. 2A, Tba $\mathrm{ADH}_{547}$ harbors three conserved motifs with several conserved amino acid residues present other ADHs. To reveal key amino acid residues for catalysis of Tba $\mathrm{ADH}_{547}$, we constructed the D195A, H199A, H262A, H266A, and H274A mutants. Following the wild-type protein expression and purification, we purified five $\mathrm{Tba}^{\mathrm{ADH}} 547$ mutant proteins (Fig. 8A).

To investigate whether the D195A, H199A, H262A, H266A, and H274A mutants cause the overall structure change of $\mathrm{Tba} \mathrm{ADH}_{547}$, we performed the $\mathrm{CD}$ analysis of the WT and mutant enzymes. The D195A, H199A, H262A, H266A, and H274A mutants displayed different conformational change from the wild-type Tba $\mathrm{ADH}_{547}$ with varied degrees (Fig. 8B). Specifically, the D195A, H266A and H274A mutants exhibited similar overall structure (Fig. 8B), which are distinct from the WT enzyme. Furthermore, the H199A substitution caused maximal change of overall structure of 
the WT enzyme, followed by three substitutions (D195A, H266A and H274A) and the H262A substitution (Fig. 8B). Thus, our observations demonstrate that the D195A, H199A, H262A, H266A, and H274A substitutions disrupt the overall structure of the WT enzyme.

Next, we investigated the ethanol oxidation and acetaldehyde reduction activities of these five mutants. Compared with the wild-type protein, the D195A mutant displayed no reduction activity and the slight weak oxidation activity (Fig. 8C), suggesting that D195 is a key residue for catalysis of this ADH. Similarly, the H262A mutant harbored the weak oxidation activity $(2.9 \%)$ and reduction activity $(6.4 \%)$, thereby indicating that $\mathrm{H} 262$ is also a key residue for catalysis. However, the H266A mutant had the higher reduction activity (134\%) but the lower oxidation activity (36\%) than the wild-type protein, suggesting that the mutation of $\mathrm{H} 266$ to Ala stimulates its reduction activity but suppresses its oxidation activity. Furthermore, the H199A and H274A mutants retained 10\% 20\% oxidation and reduction activity, demonstrating that residues H199 and H274 are involved partially in catalysis. Overall, residues D195 and $\mathrm{H} 262$ in $\mathrm{Tba}^{\mathrm{ADH}} 547$ are essential for catalysis, and residues $\mathrm{H} 199$ and H274 are also involved partially in catalysis.

\section{Discussion}

In this work, we present the biochemical characteristics and mutational studies of Tba $\mathrm{ADH}_{547}$ which is one of the ADHs of the hyperthermophilic and piezophilic euryarchaeon $T$. barophilus $\mathrm{Ch} 5$. Tba $\mathrm{ADH}_{547}$ belongs to a cluster of type III archaeal ADHs (Table 2) since this enzyme harbors three conserved motifs present in 
iron-containing $\mathrm{ADHs}$. However, $\mathrm{Tba} \mathrm{ADH}_{547}$ displays low amino acid similarity with the reported iron-containing ADHs from hyperthermophiles, including $T$. litoralis [17], T. hydrothermalis [21], Thermococcus strain ES-1 [18], P. furiosus [22] and Thermotoga hypogea [31], suggesting this ADH might be a novel type III ADH. Comparison of biochemical characteristics of iron-containing ADHs from hyperthermophiles is summarized in Table 2, displaying distinct properties for oxidation or reduction.

As expected, $\mathrm{Tba} \mathrm{ADH}_{547}$ displays maximal enzyme activity at high temperatures since it originates from the hyperthermophlilic euryarchaeon $T$. barophilus Ch5. In comparison to other thermostable type III ADHs, Tba $\mathrm{ADH}_{547}$ displays thermophilicity $5 \sim 10^{\circ} \mathrm{C}$ degrees lower than that reported for ADHs from $T$. hydrothermalis $\left(80^{\circ} \mathrm{C}\right)$ [21], T. litoralis $\left(85^{\circ} \mathrm{C}\right)[17]$ and Thermococcus strain AN1 $\left(85^{\circ} \mathrm{C}\right)$ [20]. Interestingly, the optimal temperatures of ADHs from Thermococcus strain ES-1, P. furiosus and T. hypogea exceeded $100^{\circ} \mathrm{C}$ and could not be clearly determined $[18,22,31]$. To our knowledge, we first measured the optimal temperature of acetaldehyde reduction, demonstrating the same optimal temperature for ethanol oxidation under our assay conditions. Overall, $\mathrm{Tba}_{\mathrm{ADH}} \mathrm{AD}_{57}$ harbors a relatively low optimal temperature for its activity, compared with the reported type III ADHs from hyperthermopiles.

In this work, we revealed that $\mathrm{Tba}^{\mathrm{ADH}} 547$ retains about $40 \%$ and $20 \%$ activity after being heated at $95^{\circ} \mathrm{C}$ and $100^{\circ} \mathrm{C}$ for $30 \mathrm{~min}$, respectively. The half-life of $P$. furiosus $\mathrm{ADH}$ was reported to be $7 \mathrm{~h}$ at $95^{\circ} \mathrm{C}$ [22] while the half-life of $T$. litoralis 
ADH was about $0.3 \mathrm{~h}$ at $95^{\circ} \mathrm{C}$ [17]. Thermococcus strain ES-1 and T. hypogea ADHs retain $50 \%$ activity after being heated at $95^{\circ} \mathrm{C}$ for $4 \mathrm{~h}$ and at $90^{\circ} \mathrm{C}$ for $2 \mathrm{~h}$, respectively $[32,34]$. A half-life of Thermococcus strain AN1 ADH was measured to be only 16 min at $80^{\circ} \mathrm{C}$ [20]. Furthermore, T. hydrothermalis $\mathrm{ADH}$ abolishes $50 \%$ activity at $80^{\circ} \mathrm{C}$ for $0.25 \mathrm{~h} \mathrm{[21].} \mathrm{Thus,} \mathrm{the} \mathrm{type} \mathrm{III} \mathrm{ADHs} \mathrm{from} \mathrm{hyperthermophiles} \mathrm{exhibits} \mathrm{strong}$ thermostability, but their degree of thermostability varies with different their host sources.

Maximal activity of $\mathrm{Tba}_{\mathrm{ADH}} \mathrm{AD}_{47}$ for ethanol oxidation was observed at $\mathrm{pH} 8.5$, which is similar to other type III ADHs from T. litoralis and Thermococcus strain ES-1 [17-18]. Tba $\mathrm{ADH}_{547}$ differs significantly from other extremophilic type III ADHs displaying a lower $\mathrm{pH}$ optimum than the type III-ADHs from T. hydrothermalis, P. furiosus and T. hypogea $[21-22,31]$. However, maximal activity of $\mathrm{Tba}_{\mathrm{ADH}} \mathrm{AD}_{54}$ for acetaldehyde reduction was measured at $\mathrm{pH} 7.0$, suggesting that this $\mathrm{ADH}$ displays various optimal $\mathrm{pH}$ for oxidation and reduction reactions. Similar observations are found in the reported ADHs from Thermococcus strain ES-1 [18], T. hydrothermalis [21], P.furiosus [22], and T. hypogea [31].

Although the members of the Fe-ADH family are described as iron-activated alcohol dehydrogenases, these enzymes can be activated by a range of divalent cations, including zinc, nickel, magnesium, copper, cobalt, or manganese (e.g., [32-35], besides iron. To date, divalent cations are needed for a type III ADH activity, among which Fe is essentially ADHs from Thermococcales. However, we found that Tba $\mathrm{ADH}_{547}$ is the only known example of a type III archaeal ADH that is dependent 
on a divalent ion for its oxidation activity. Interestingly, this ADH displays maximal oxidation activity in the presence of added $\mathrm{Mn}^{2+}$. However, $\mathrm{Tba} \mathrm{ADH}_{547}$ can catalyze acetaldehyde reduction reaction in the absence of a divalent ion and displays maximal activity in the presence of $\mathrm{Fe}^{2+}$ for acetaldehyde reduction.

Among the characterized archaeal ADHs capable of oxidizing primary alcohols, all others isolated from Thermococcales species exhibit a greater preference for 1-butanol over ethanol as a substrate as observed for $\mathrm{Tba}^{\mathrm{ADH}} \mathrm{H}_{57}$. Similar to the ADHs from Thermococcus strain AN1 [20], T. litoralis [17] and Thermococcus strain ES-1 [18], Tba $\mathrm{ADH}_{547}$ shows a higher preference for primary alcohols of longer chain such as 1-hexyl alcohols. However, AdhD from P. furiosus essentially cannot process ethanol and has a strong preference for 1-butanol [36], and the ADH from $T$. litoralis has a marked preference for aliphatic primary alcohols [17]. In contrast to Tba $\mathrm{ADH}_{547}$, Thermococcus sibiricus $\mathrm{ADH}$, which belongs to the short-chain $\mathrm{ADH}$ family, demonstrates a preference for ethanol over 1-butanol, but is most probably a secondary alcohol dehydrogenase as shown by its strong preference for 2-butanol over 1-butanol [37]. In addition, similar to the ADHs from all the Thermococcales species listed above, Tba $\mathrm{ADH}_{547}$ cannot utilize methanol as a substrate. In this respect, $\mathrm{Tba} \mathrm{ADH}_{547}$ and $\mathrm{ADHs}$ from the other Thermococcales differ from the ADHs found outside the Thermococcales order, such as Picrophilus torridus ADH [38] or Thermoplasma acidophilum ADH [39], which retain some level of activity with methanol.

As shown in Table 2, the $K_{\mathrm{m}}$ values of $\mathrm{Tba}^{\mathrm{ADH}} 547$ for ethanol oxidation and 
acetaldehyde reduction are higher than those of the reported ADHs from the other

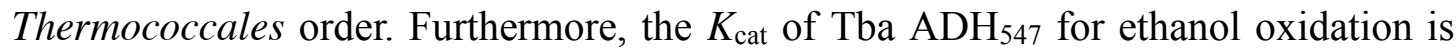
lower than that of the reported ADHs from the other Thermococcales order. However, the $K_{\text {cat }}$ of $\mathrm{Tba} \mathrm{ADH}_{547}$ for acetaldehyde reduction is maximum among the all the reported ADHs listed above. Importantly, the $K_{\text {cat }} / K_{\mathrm{m}}$ of Tba $\mathrm{ADH}_{547}$ for acetaldehyde reduction is 670 -fold higher than that for ethanol oxidation, suggesting that this ADH displays higher catalytic efficiencies for acetaldehyde reduction than ethanol oxidation as suggested by Fernandez et al. who proposed that type III ADHs from microorganisms contributed to aldehyde detoxication rather than alcohol oxidation [40]. Similarly, 13-fold, 49-fold and 3.3-fold higher $K_{\text {cat }} K_{\mathrm{m}}$ values for acetaldehyde reduction than ethanol oxidation are observed for the ADHs from Thermococcus strain ES-1, P. furiosus and T. hypogea $[18,22,31]$, respectively. Thus, Tba $\mathrm{ADH}_{547}$ displays higher $K_{\text {cat }} / K_{\mathrm{m}}$ values for acetaldehyde reduction over ethanol oxidation than other ADHs from hyperthermoplies listed above. Since T. barophilus Ch5 is an anaerobic euryachaeon [23], the catalytic activity of $\mathrm{Tba}^{\mathrm{ADH}} \mathrm{D}_{547}$ for ethanol synthesis is far greater than that for ethanol oxidation, which might recover the $\mathrm{NAD}^{+}$required for another Entner-Doudoroff glycolytic (ED) pathway under anaerobic conditions.

Alignment of amino acid sequences from type III ADH demonstrates that they possess a conserved motif III with the three highly conserved histidine residues. Mutational studies show that the H263R, H267A and H277A mutations resulted in the E. coli propanediol oxidoreductase without catalytic activity [41]. Crystal structure of this enzyme shows that His 26 and His277 are strictly essential metal-ion ligands, and 
His 267 could interact with the substrate, and therefore should be involved in catalysis, but not in metal-binding [13]. Similar to E. coli propanediol oxidoreductase, Tba $\mathrm{ADH}_{547}$ harbors the corresponding residues $\mathrm{H} 262, \mathrm{H} 266$ and $\mathrm{H} 274$ in the conserved motif III. Our mutational data show that the H262A, H266A and H274A Tba $\mathrm{ADH}_{547}$ mutants retain $5 \%, 40 \%$, and $25 \%$ oxidation activity, respectively. Thus, these observations suggest that a combination of residues $\mathrm{H} 262, \mathrm{H} 266$ and $\mathrm{H} 274$ is essential for catalysis. Surprisingly, the mutation of H266 to Ala results in 1.4-fold increase in reduction activity while the mutations of $\mathrm{H} 262$ and $\mathrm{H} 274$ to Ala lead to $75 \%$ and $90 \%$ reduction activity loss, respectively, which might be caused by overall conformational disruption due to the H262A, H266A and H274A substitutions. To our knowledge, we first revealed the function the three highly conserved histidine residues in the motif III of type III $\mathrm{ADH}$ in acetaldehyde reduction using $\mathrm{Tba}^{\mathrm{ADH}} \mathrm{AD}_{547}$ as a target, demonstrating that residue $\mathrm{H} 262$ and $\mathrm{H} 274$ are involved in catalyzing acetaldehyde reduction reaction.

In addition to the motif II, motif II (DxxxH) with a highly conserved His residue and an Asp residue is widely present in type III ADHs. The crystal structure of $T$. thioreducens ADH shows that the conserved residues Asp193 and His197 interact with Fe atom plus residues His260 and His272 located in the conserved motif III [15]. The conserved His residue and an Asp residue in motif II are observed in the crystal structures of other type III ADHs. However, the biochemical function of the conserved His residue and an Asp residue in motif II has not been clarified. In this work, we constructed the D195A and H199A Tba $\mathrm{ADH}_{547}$ mutants and investigated 
their activity for ethanol oxidation and acetaldehyde reduction. Note that residues D195 and H199 are analogous to residues D193 and H197 in T. thioreducens ADH. Our observations demonstrate that the D195A mutant retains slight weak activity for ethanol oxidation, and lacks acetaldehyde reduction activity. Furthermore, the H199A mutant harbors the compromised activity. Similar to the H262A, H266A and H274A substitutions, the D195A and H199A substitutions disrupt the overall structural change, which might cause the activity loss of the wild-type $\mathrm{Tba} \mathrm{ADH}_{547}$. Thus, residues D195 and $\mathrm{H} 199$ in $\mathrm{Tba}_{\mathrm{ADH}} \mathrm{A}_{57}$ are responsible for catalysis and maintaining their structural roles.

\section{Conclusion}

Herein, we present biochemical characterization of $\mathrm{Tba}_{\mathrm{ADH}} \mathrm{A}_{547}$, displaying same optimal temperature $\left(75^{\circ} \mathrm{C}\right)$ for oxidation and reduction activities. However, this ADH has distinct optimal $\mathrm{pH}$ for ethanol oxidation and acetaldehyde reduction. Interestingly, $\mathrm{Tba} \mathrm{ADH}_{547}$ can catalyze ethanol oxidation with a divalent ion, which is sharply contrasted to the reported ADHs. Furthermore, $\mathrm{Tba}^{\mathrm{ADH}} \mathrm{A}_{57}$ exhibits distinct divalent ion preference: $\mathrm{Mn}^{2+}$ for ethanol oxidation and $\mathrm{Fe}^{2+}$ for acetaldehyde reduction. Primary alcohols are the favored substrates for oxidation of $\mathrm{Tba}^{\mathrm{ADH}} \mathrm{A}_{547}$, with 1-butanol yielding the highest efficiency. Furthermore, butyaldehyde is a more suitable substrate for reduction of $\mathrm{Tba} \mathrm{ADH}_{547}$ than acetaldehyde. We revealed that residue D195, $\mathrm{H} 199, \mathrm{H} 262$ and $\mathrm{H} 234$ in $\mathrm{Tba}^{\mathrm{ADH}} 547$ are involved in catalysis by mutational studies. Overall, our findings suggest that $\mathrm{Tba}^{\mathrm{ADH}} \mathrm{A}_{57}$ might have a biotechnological potential for the biotransformation reaction due to its unique biochemical characteristics and high activity at high temperature. 


\section{Author Contributions}

LZ and PO designed experiments; DJ, YL and LW performed experiments; LZ, KD, QL and PO analyzed data; LZ, KD, QL and PO wrote and revised the paper.

\section{Declaration of Competing Interest}

All authors declare that there is no conflict of interests regarding the publication of this paper.

\section{Funding}

This work was supported by the Provincial Natural Science Foundation of Jiangsu Province (No. BK20191219 and No. BK20180940), High Level Talent Support Program of Yangzhou University and the Academic Leader of Middle and Young People of Yangzhou University Grant.

\section{Figure legends}

Fig. 1. Phylogenetic analysis of $\mathrm{Tba}_{\mathrm{ADH}} \mathrm{A}_{61}$ and $\mathrm{Tba} \mathrm{ADH}_{547}$. A. Phylogenetic tree of

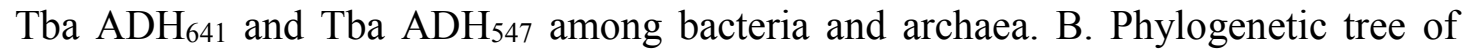
Tba $\mathrm{ADH}_{547}$ among bacteria and archaea.

Fig. 2. Sequence alignment of type III ADHs from bacteria, archaea and eukaryotes. Three conserved motifs (motif I: GGGS; motif II: DxxxH; motif III: the three highly conserved histidine residues) are boxed. The consensus residues are colored. The residues for engineering Tba $\mathrm{ADH}_{547}$ mutants are marked by an asterisk. Tba: Thermococcus barophilus (GenBank: ALM74514.1 for $\mathrm{ADH}_{547}$ and $\mathrm{ALM} 74601$ for $\mathrm{ADH}_{641}$ ); Tan: Thermococcus strain AN1, (GenBank: WP_010477684); Tth: Thermococcus thioreducens (GenBank: ASJ12775); Tko: Thermococcus kodakarensis 
(GenBank: WP_011249959 for ADH1 and WP_083755808 for ADH2); Tpa: Thermococcus paralvinellae (GenBank: AHF80371); Thy: Thermococcus hydrothermalis (GenBank: CAA74334); Tsp: Thermococcus sp. (GenBank: AAB63011); Tli: Thermococcus litoralis (GenBank: AAB63011); Pfu: Pyrococcus furiosus (GenBank: WP_011011187); Zmo: Zymomonas mobilis (GenBank: TWE26216); Sce: Saccharomyces cerevisiae (GenBank: GAX68104).

Fig. 3. Tba $\mathrm{ADH}_{547}$ can catalyze ethanol oxidation and acetaldehyde reduction reaction at high temperature. A. Overexpression and purification of $\mathrm{Tba} \mathrm{ADH}_{547}$ protein. M: protein marker. B. The optimal reaction temperature of $\mathrm{Tba} \mathrm{ADH}_{547}$ activity. The ethanol oxidation reactions of $\mathrm{Tba}^{\mathrm{ADH}_{547}}$ were performed in the presence of $\mathrm{Mn}^{2+}$ at different temperatures at $\mathrm{pH}$ 8.5. The acetaldehyde reduction reactions of $\mathrm{Tba} \mathrm{ADH}_{547}$ were performed in the presence of $\mathrm{Fe}^{2+}$ at different temperatures at $\mathrm{pH}$ 7.0.

Fig. 4. Thermostability of $\mathrm{Tba} \mathrm{ADH}_{547}$ activity. A. The thermostability for reduction reaction catalyzed by $\mathrm{Tba} \mathrm{ADH}_{547}$. The heated $\mathrm{Tba}_{\mathrm{ADH}} \mathrm{AD}_{57}$ at varied temperatures for 30 min was employed to perform the acetaldehyde reduction reactions in the presence of $\mathrm{Fe}^{2+}$ at $75^{\circ} \mathrm{C}$ at $\mathrm{pH} 7.0$. $\mathrm{CK}$ : the reaction with the non-heated enzyme. B. The thermostability for oxidation reaction catalyzed by Tba $\mathrm{ADH}_{547}$. The heated Tba $\mathrm{ADH}_{547}$ at $100^{\circ} \mathrm{C}$ for varied times was employed to perform the ethanol oxidation reactions in the presence of $\mathrm{Mn}^{2+}$ at $75^{\circ} \mathrm{C}$ at $\mathrm{pH}$ 8.5. $\mathrm{CK}$ : the reaction with the non-heated enzyme.

Fig. 5. Effects $\mathrm{pH}$ and divalent metal ions on $\mathrm{Tba}_{\mathrm{ADH}} \mathrm{A}_{47}$ activity. A. Effect of $\mathrm{pH}$ on 
Tba $\mathrm{ADH}_{547}$ activity. The ethanol oxidation reactions of $\mathrm{Tba} \mathrm{ADH}_{547}$ were performed in the presence of $\mathrm{Mn}^{2+}$ at $75^{\circ} \mathrm{C}$ at varied $\mathrm{pHs}$. The acetaldehyde reduction reactions of $\mathrm{Tba} \mathrm{ADH}_{547}$ were performed in the presence of $\mathrm{Fe}^{2+}$ at $75^{\circ} \mathrm{C}$ at varied $\mathrm{pHs}$. $\mathrm{CK}$ : the reaction without enzyme. B. Effects divalent metal ions on $\mathrm{Tba}^{\mathrm{ADH}} \mathrm{AD}_{547}$ activity. The ethanol oxidation reactions of $\mathrm{Tba} \mathrm{ADH}_{547}$ were performed in the presence of varied divalent metal ions at $75^{\circ} \mathrm{C}$ at $\mathrm{pH} 8.5$. The acetaldehyde reduction reactions of Tba $\mathrm{ADH}_{547}$ were performed in the presence of varied divalent metal ions at $75^{\circ} \mathrm{C}$ at $\mathrm{pH}$ 7.0. CK: the reaction without enzyme. EDTA: the reaction with $10 \mathrm{mM}$ EDTA.

Fig. 6. Substrate specificity of the oxidation activity and the reduction activity of Tba $\mathrm{ADH}_{547}$. A. Substrate specificity of the oxidation activity of $\mathrm{Tba} \mathrm{ADH}_{547}$. The oxidation reactions of $\mathrm{Tba}^{\mathrm{ADH}} \mathrm{H}_{547}$ were performed in the presence of $\mathrm{Mn}^{2+}$ at $75^{\circ} \mathrm{C}$ at $\mathrm{pH} 8.5$ using varied alcohols as the substrates. B. Substrate specificity of the reduction activity of $\mathrm{Tba} \mathrm{ADH}_{547}$. The reduction reactions of $\mathrm{Tba}^{\mathrm{ADH}} \mathrm{A}_{547}$ were performed in the presence of $\mathrm{Fe}^{2+}$ at $75^{\circ} \mathrm{C}$ at $\mathrm{pH} 7.0$ using varied aldehydes as the substrates.

Fig. 7. The Lineweaver-Burk plots for ethanol oxidation and acetaldehyde reduction of $\mathrm{Tba} \mathrm{ADH}_{547}$. (A) The Lineweaver-Burk plot for ethanol oxidation of $\mathrm{Tba} \mathrm{ADH}_{547}$. The oxidation reactions of Tba $\mathrm{ADH}_{547}$ were performed in the presence of $\mathrm{Mn}^{2+}$ at $75^{\circ} \mathrm{C}$ at $\mathrm{pH} 8.5$ using ethanol with varied concentrations as the substrates. The Lineweaver-Burk curve was generated by plotting the reciprocal of each ethanol concentration as a horizontal ordinate and the reciprocal of each reaction rate as a vertical coordinate with a linear regression. (B) The Lineweaver-Burk plot for acetaldehyde reduction of $\mathrm{Tba} \mathrm{ADH}_{547}$. The reduction reactions of $\mathrm{Tba}^{\mathrm{ADH}} \mathrm{D}_{547}$ were 
performed in the presence of $\mathrm{Fe}^{2+}$ at $75^{\circ} \mathrm{C}$ at $\mathrm{pH} 7.0$ using acetaldehyde with varied concentrations as the substrates. The Lineweaver-Burk curve was generated by plotting the reciprocal of each acetaldehyde concentration as a horizontal ordinate and the reciprocal of each reaction rate as a vertical coordinate with a linear regression.

Fig. 8. Purification and the activity assays of the $\mathrm{Tba}^{\mathrm{ADH}} \mathrm{AD}_{57}$ mutants. A. Purification of the WT, D195A, H199A, H262A, H266A and H274A mutant Tba $\mathrm{ADH}_{547}$ proteins. WT: wild-type; M: protein marker. B. CD analysis of the WT and mutant Tba $\mathrm{ADH}_{547}$ proteins. The mean residue ellipticity was recorded with different color line for the WT and mutant $\mathrm{Tba} \mathrm{ADH}_{547}$ proteins as indicated by monitoring changes in secondary structure with scanning from $200 \mathrm{~nm}$ to $250 \mathrm{~nm}$. The CD spectra of the WT, D195A, H199A, H262A, H266A and H274A mutant Tba $\mathrm{ADH}_{547}$ proteins are colored with black, red, yellow, green, cyan and blue, respectively. C. The activity assays of the Tba $\mathrm{ADH}_{547}$ D195A, H199A, H262A, H266A and H274A mutants. The oxidation reactions of the $\mathrm{Tba} \mathrm{ADH}_{547}$ mutants were performed in the presence of $\mathrm{Mn}^{2+}$ at $75^{\circ} \mathrm{C}$ at $\mathrm{pH} 8.5$ using ethanol as the substrate. The reduction reactions of the $\mathrm{Tba} \mathrm{ADH}_{547}$ mutants were performed in the presence of $\mathrm{Fe}^{2+}$ at $75^{\circ} \mathrm{C}$ at $\mathrm{pH} 7.0$ using acetaldehyde as the substrate. 


\section{References}

1. J.A. Littlechild, J.E. Guy, M.N. Isupov, Hyperthermophilic dehydrogenase enzymes, Biochem. Soc. Trans. 32 (2004) 255-258.

2. H. Radianingtyas, P.C. Wright, Alcohol dehydrogenases from thermophilic and hyperthermophilic archaea and bacteria, FEMS Microbiol. Rev. 27 (2003) 593-616.

3. D.R. Thatcher, The complete amino acid sequence of three alcohol dehydrogenase alleloenzymes $(A d h-\mathrm{N} 11, A d h$-s and $A d h$-UF) from the fruitfly Drosophila melanogaster, Biochem. J. 187 (1980) 875-886.

4. H. Eklund, B. Nordstro“m, E. Zeppezauer, G. So“derlund, I. Ohlsson, T. Boiwe, B.-O. So“derberg, O. Tapia, C.-I. Brände'n, Å. Åkeson, Three-dimensional structure of horse liver alcohol dehydrogenase at $2.4 \AA$ resolution, J. Mol. Biol. 102 (1976) 27-59.

5. D. Neale, R. K. Scopes, J. M. Delly, R. E. H. Wettenhall, The two alcohol dehydrogenases of Zymomonas mobilis: purification by differential dye ligand chromatography, molecular characterization and physiological roles, Eur. J. Biochem. 154 (1986) 119-124.

6. T. Conway, G. W. Sewell, Y. A. Osman, L. O. Ingram, Cloning and sequencing of the alcohol dehydrogenase II gene from Zymomonas mobilis, J. Bacteriol. 169 (1987) 2591-2597. 
7. V. M. Williamson, C. E. Paquin, Homology of Saccharomyces cerevisiae ADH4 to an iron-activated alcohol dehydrogenase from Zymomonas mobilis, Mol. Gen. Genet. 209 (1987) 374-381.

8. T. Conway, L. O. Ingram, Similarity of Escherichia coli propanediol oxidoreductase (fucO product) and an unusual alcohol dehydrogenase from Zymomonas mobilis and Saccharomyces cerevisiae, J. Bacteriol. 171 (1989) 3754-3759.

9. J. S. Youngleson, W. A. Jones, D. T. Jones, D. R. Woods, Molecular analysis and nucleotide sequence of the adh1 gene encoding an NADPH-dependent butanol dehydrogenase in the gram-positive anaerobe Clostridium acetobutylicum, Gene 78 (1989) 355-364.

10. K. A. Walter, G. N. Bennett, E. T. Papoutsakis, Molecular characterization of two Clostridium acetobutylicum ATCC 824 butanol dehydrogenase isozyme genes, J. Bacteriol. 174 (1992) 7149-7158.

11. G. E. De Vries, N. Arfman, P. Terpstra, L. Dijkhuizen. Cloning, expression, and sequence analysis of the Bacillus methanolicus $\mathrm{C} 1$ methanol dehydrogenase gene. J. Bacteriol. 174 (1992) 5346-5353.

12. Y. Deng, Z. Wang, S. Gu, C. Ji, K. Ying, Y. Xie, Y. Mao, Cloning and characterization of a novel human alcohol dehydrogenase gene (ADHFe1), DNA Seq. 13 (2002) 301-306.

13. C. Montella, L. Bellsolell, R. Pérez-Luque, J. Badía, L. Baldoma, M. Coll, J. Aguilar, Crystal structure of an iron-dependent group III dehydrogenase that 
interconverts L-lactaldehyde and L-1,2-propanediol in Escherichia coli. J Bacteriol. 187 (2005) 4957-4966.

14. J. Moon, H. Lee, S. Park, J. Song, M. Park, H. Park, J. Sun, J. Park, B. Kim, J. Kim, Structures of iron-dependent alcohol dehydrogenase 2 from Zymomonas mobilis ZM4 with and without NAD+ cofactor, J. Mol. Biol. 407 (2011) 413-424.

15. S.B. Larson, J.A. Jones, A. McPherson, The structure of an iron-containing alcohol dehydrogenase from a hyperthermophilic archaeon in two chemical states, Acta Crystallogr. F Struct. Biol. Commun. 75 (2019) 217-226.

16. R. Schwarzenbacher, F. von Delft, J. M. Canaves, L. S. Brinen, X. Dai, A. Deacon, M. et al, Crystal structure of an iron-containing 1,3-propanediol dehydrogenase (TM0920) from Thermotoga maritime at $1.3 \AA$ resolution. Proteins, 54 (2004) 174-177.

17. K. Ma, F.T. Robb, M.W. Adams, Purification and characterization of NADP-specific alcohol dehydrogenase and glutamate dehydrogenase from the hyperthermophilic archaeon Thermococcus litoralis, Appl. Environ. Microbiol. 60 (1994) 562-568.

18. K. Ma, H.J. Loessner, J. Heider, M.K. Johnson, M.W.W. Adams, Effects of elemental sulfur on the metabolism of the deep-sea hyperthermophilic archaeon Thermococcus strain ES-1: characterization of a sulfur-regulated, non-heme iron alcohol dehydrogenase, J. Bacteriol. 177 (1995) 4748-4756.

19. X. Ying, A.M. Grunden, L. Nie, M.W. Adams, K. Ma, Molecular characterization of the recombinant iron-containing alcohol dehydrogenase from the 
hyperthermophilic Archaeon, Thermococcus strain ES1, Extremophiles, 13 (2009) 299-311.

20. D. Li, K.J. Stevenson, Purification and sequence analysis of a novel NADP(H)-dependent type III alcohol dehydrogenase from Thermococcus strain AN1, J. Bacteriol. 179 (1997) 4433-4437.

21. E. Antoine, J.L. Rolland, J.P. Raffin, J. Dietrich, Cloning and over-expression in Escherichia coli of the gene encoding NADPH group III alcohol dehydrogenase from Thermococcus hydrothermalis. Characterization and comparison of the native and the recombinant enzymes, Eur. J. Biochem. 264 (1999) 880-889.

22. Ma K, Adams MWW (1999) An unusual oxygen-sensitive, iron and zinc-containing alcohol dehydrogenase from the hyperthermophilic archaeon Pyrococcus furiosus. J Bacteriol 181:1163-1170.

23. V.T. Marteinsson, J.L. Birrien, A.L. Reysenbach, M. Vernet, D. Marie, A. Gambacorta, P Messner, U.B. Sleytr, D. Prieur, Thermococcus barophilus sp. nov., a new barophilic and hyperthermophilic archaeon isolated under high hydrostatic pressure from a deep-sea hydrothermal vent, Int.J. Syst. Bacteriol. 49 (1999) 351-359.

24. P. Oger, T.G. Sokolova, D.A. Kozhevnikova, E.A. Taranov, P. Vannier, H.S. Lee, K.K. Kwon, S.G. Kang, J.H. Lee, E.A. Bonch-Osmolovskaya, A. V. Lebedinsky, Complete genome sequence of the hyperthermophilic and piezophilic archaeon Thermococcus barophilus Ch5, capable of growth at the expense of hydrogenogenesis from carbon monoxide and formate, Genome Announc. 4 
(2016).

25. K.M. Kwon, S.G. Kang, T.G. Sokolova, S.S. Cho, Y.J. Kim, C.H. Kim, ST. Kwon, Characterization of a family B DNA polymerase from Thermococcus barophilus Ch5 and its application for long and accurate PCR, Enzyme Microb. Technol. 86 (2016) 117-126.

26. Y. Wang, L. Zhang, X. Zhu, Y. Li, H. Shi, P. Oger, Z. Yang, Biochemical characterization of a thermostable endonuclease $\mathrm{V}$ from the hyperthermophilic euryarchaeon Thermococcus barophilus Ch5, Int. J. Biol. Macromol. 117 (2018) $17-24$.

27. H. Shi, Q. Gan, D. Jiang, Y. Wu, Y. Yin, H. Hou, H. Chen, Y. Xu, L. Miao, Z. Yang, P. Oger, Biochemical characterization and mutational studies of a thermostable uracil DNA glycosylase from the hyperthermophilic euryarchaeon Thermococcus barophilus Ch5, Int. J. Biol. Macromol. 134 (2019) 846-855.

28. H. Shi, Y. Huang, Q. Gan, M. Rui, H. Chen, C. Tu, Z. Yang, P. Oger, L. Zhang, Biochemical characterization of a thermostable DNA ligase from the hyperthermophilic euryarchaeon Thermococcus barophilus Ch5, Appl. Microbiol. Biotechnol. 103 (2019) 3795-3806.

29. Q. Gan, M. He, H. Shi, Z. Yang, P. Oger, L. Ran, L Zhang, Characterization of a Family IV uracil DNA glycosylase from the hyperthermophilic euryarchaeon Thermococcus barophilus Ch5, Int. J. Biol.Macromol. 146 (2020) 475-481.

30. M. Gouy, S. Guindon, O. Gascuel, SeaView version 4: a multiplatform graphical user interface for sequence alignment and phylogenetic tree building, Mol. Biol. 
Evol. 27 (2010) 221-224.

31. X. Ying, Y. Wang, H.Badiei, V. Karanassios, K. Ma, Purification and characterization of an iron-containing alcohol dehydrogenase in extremely thermophilic bacterium Thermotoga hypogea, Arch. Microbiol. 187 (2007) 499-510.

32. S. Elleuche, K. Fodor, B. Klippel, H.A. von der, M. Wilmanns, G. Antranikian, Structural and biochemical characterisation of a $\mathrm{NAD}(+)$-dependent alcohol dehydrogenase from Oenococcus oeni as a new model molecule for industrial biotechnology applications, Appl. Microbiol. Biotechnol. 97 (2013) 8963-8975.

33. G. Sulzenbacher, K. Alvarez, R.H. Van Den Heuvel, C, Versluis, S, Spinelli, V, Campanacci, et al. Crystal structure of E. coli alcohol dehydrogenase YqhD: evidence of a covalently modified NADP coenzyme, J. Mol. Biol. 342 (2004) 489-502.

34. S. Elleuche, K. Fodor, H.A. von der, B. Klippel, M. Wilmanns, G. Antranikian, Group III alcohol dehydrogenase from Pectobacterium atrosepticum: insights into enzymatic activity and organization of the metal ion-containing region, Appl. Microbiol. Biotechnol. 98 (2014) 4041-4051.

35. J. Extance, S.J. Crennell, K. Eley, R. Cripps, D.W. Hough, M.J. Danson, Structure of a bifunctional alcohol dehydrogenase involved in bioethanol generation in Geobacillus thermoglucosidasius, Acta Crystallogr. D Biol. Crystallogr. 69 (2013) 2104-2115.

36. R. Machielsen, A.R. Uria, S.W. Kengen, J. van der Oost, Production and 
characterization of a thermostable alcohol dehydrogenase that belongs to the aldo-keto reductase superfamily, Appl. Environ. Microbiol. 72 (2006) 233-238.

37. T.N. Stekhanova, A.V. Mardanov, E.Y. Bezsudnova, V.M. Gumerov, N.V. Ravin, K.G. Skryabin, V.O. Popov, Characterization of a thermostable short-chain alcohol dehydrogenase from the hyperthermophilic archaeon Thermococcus sibiricus, Appl. Environ. Microbiol. 76 (2010) 4096-4098.

38. M. Hess, G. Antranikian, Archaeal alcohol dehydrogenase active at increased temperatures and in the presence of organic solvents, Appl. Microbiol. Biotechnol. 77 (2008) 1003-1013.

39. E.N. Marino-Marmolejo, A.D. León-Rodríguez, A.P.B. de la Rosa, L. Santos, Heterologous expression and characterization of an alcohol dehydrogenase from the archaeon Thermoplasma acidophilum, Mol. Biotechnol. 42 (2009) 61-67.

40. M.R Fernandez, J.A. Biosca, A. Norin, H. JoÃrnvall, X. PareÂs, Class III alcohol dehydrogenase from Saccharomyces cerevisiae: Structural and enzymatic features differ toward the human/mammalian forms in a manner consistent with functional needs in formaldehyde detoxication, FEBS Lett. 370 (1995) 23-26.

41. N. Obradors, E. Cabiscol, J. Aguilar, J. Ros, Site-directed mutagenesis studies of the metal-binding center of the iron-dependent propanediol oxidoreductase from Escherichia coli, Eur. J. Biochem. 258 (1998) 207-213. 
Table 1 Sequences of the oligonucleotides used to clone the $\mathrm{Tba} \mathrm{ADH}_{547}$ gene and construct its mutants

\begin{tabular}{ll}
\hline Name & Sequence $\left(5^{\prime}-3^{\prime}\right)$ \\
\hline Tba ADH ${ }_{547} \mathrm{~F}$ & GGGAATTCCATATGCAGTTCTTCAGCTTAAAGAC \\
Tba ADH 547 R & CCGCTCGAGATCATAGAAGGCTCTCTTATAC \\
D195A F & AAGGAACAGCGGACTGGCTGTTCTGGTGCAC \\
D195A R & GCCAGTCCGCTGTTCCTTGCAACTTCTTTTG \\
H199A F & GACTGGATGTTCTGGTGGCCGGAATTGAAGCT \\
H199A R & $\underline{\text { GCCACCAGAACATCCAGTCCGCTGTTCCTTGC }}$ \\
H262A F & CCCGTTTAGGCTTGTGCGCCAGCTTAAGCCAT \\
H262A R & $\underline{\text { GCGCACAAGCCTAAACGGGCATTAAGAAAAGC }}$ \\
H266A F & TGTGCCACAGCTTAAGCGCTAAAGCGGCTTGG \\
H266A R & $\underline{\text { GCGCTTAAGCTGTGGCACAAGCCTAAACGGGC }}$ \\
H274A F & CGGCTTGGATTGCCCCTGCCGGCTTGTTAAAT \\
H274A R & GCAGGGGCAATCCAAGCCGCTTTATGGCTTAA \\
\hline
\end{tabular}

The italic bases represent restriction sites.

The substitution bases are underlined. 
Table 2 Comparisons of biochemical characteristics of iron-containing ADH members from hydrothermophiles.

\begin{tabular}{|c|c|c|c|c|c|c|c|}
\hline \multicolumn{2}{|l|}{ Organism } & \multirow{2}{*}{$\begin{array}{l}\mathrm{T} /{ }^{\circ} \mathrm{C} \\
\text { optimum } \\
75\end{array}$} & \multirow{2}{*}{$\begin{array}{l}\mathrm{pH} \\
\text { optimum } \\
8.5\end{array}$} & \multirow{2}{*}{$\begin{array}{c}K_{\mathrm{m}} \\
(\mathrm{mM})\end{array}$} & \multirow{2}{*}{$\begin{array}{r}K_{\text {cat }} \\
\left(\mathrm{s}^{-1}\right) \\
0.27\end{array}$} & $\begin{array}{l}K_{\mathrm{cat}} / K_{\mathrm{m}} \\
\left(\mathrm{s}^{-1} \mathrm{M}^{-1}\right)\end{array}$ & Reference \\
\hline \multirow{2}{*}{ T. barophilus } & Oxidation $^{\mathrm{a}}$ & & & & & 2.9 & \multirow{2}{*}{ This work } \\
\hline & Reduction $^{\mathrm{b}}$ & 75 & 7.0 & 34.5 & 69 & $2.0 \times 10^{3}$ & \\
\hline \multirow{2}{*}{$\begin{array}{l}\text { Thermococcus } \\
\text { strain AN1 }\end{array}$} & Oxidation & 85 & $6.8-7.0$ & ND & ND & ND & \multirow{2}{*}{ [20] } \\
\hline & Reduction & ND & 7.0 & 0.12 & ND & ND & \\
\hline \multirow{2}{*}{ T. litoralis } & Oxidation & 85 & 8.8 & 11 & 26 & $2.3 \times 10^{3}$ & \multirow{2}{*}{ [17] } \\
\hline & Reduction & ND & ND & 0.4 & ND & ND & \\
\hline \multirow{2}{*}{ T. hydrothermalis } & Oxidation & 80 & 10.5 & ND & ND & ND & \multirow{2}{*}[21]{} \\
\hline & Reduction & ND & 7.5 & ND & ND & ND & \\
\hline \multirow{2}{*}{$\begin{array}{l}\text { Thermococcus } \\
\text { strain ES-1 }\end{array}$} & Oxidation & $>95$ & $8.8-10.4$ & 8.0 & 48 & $6.0 \times 10^{3}$ & \multirow{2}{*}{ [18] } \\
\hline & Reduction & ND & ND & 0.25 & 19 & $7.6 \times 10^{4}$ & \\
\hline \multirow{2}{*}{ P. furiosus } & Oxidation & $>95$ & $9.4-10.2$ & 29.4 & 19 & $6.5 \times 10^{2}$ & \multirow{2}{*}{ [22] } \\
\hline & Reduction & ND & ND & 0.17 & 5.5 & $3.2 \times 10^{4}$ & \\
\hline \multirow{2}{*}{ T. hypogea } & Oxidation & $>95$ & 11.0 & 9.7 & 14 & $1.5 \times 10^{3}$ & \multirow{2}{*}[31]{} \\
\hline & Reduction & ND & 8.0 & 3.1 & 15 & $5.0 \times 10^{3}$ & \\
\hline
\end{tabular}

a: Ethanol oxidation reaction; b: Acetaldehyde reduction; ND: Not determined 

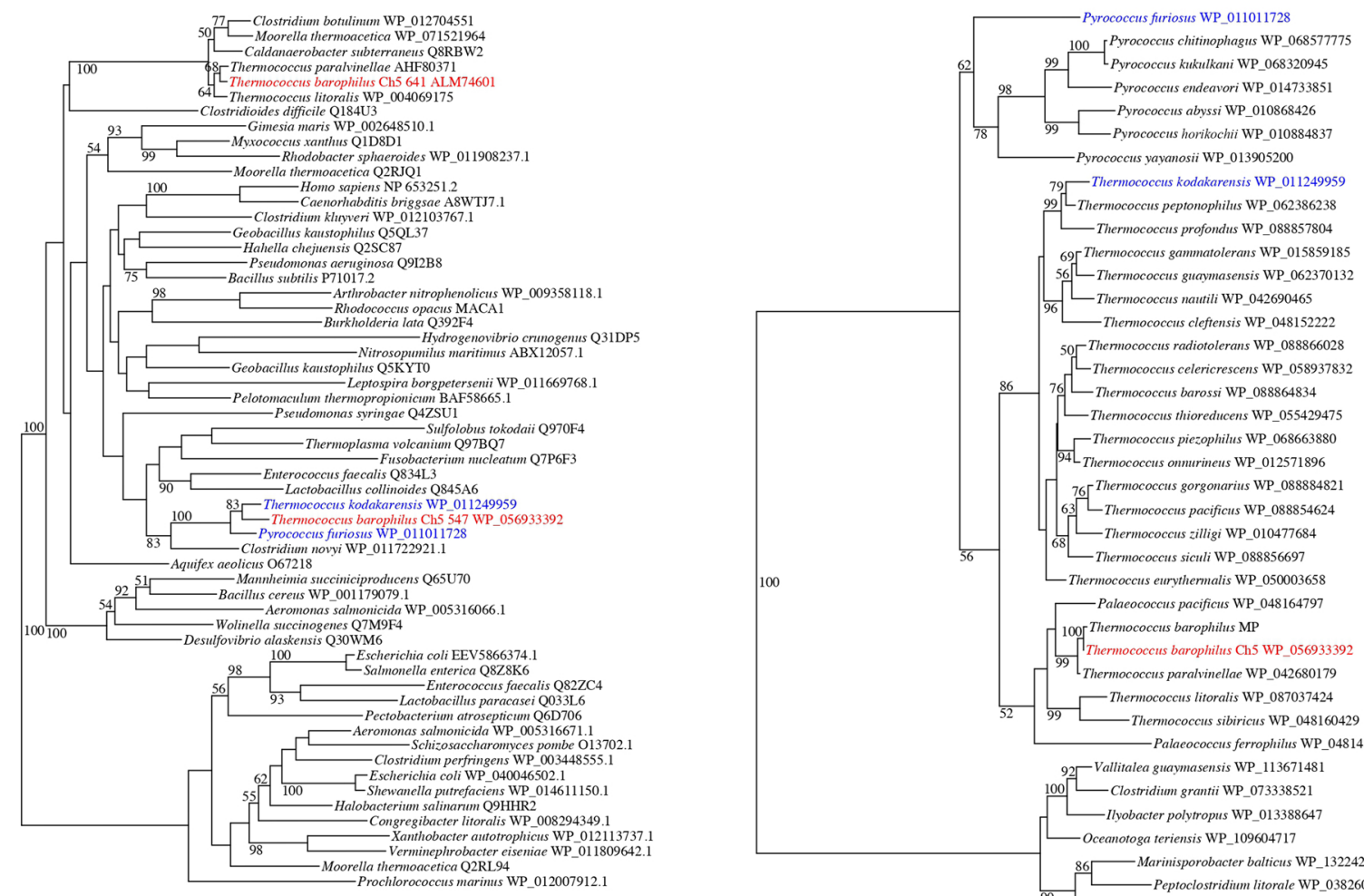

-Palaeococcus ferrophilus WP_048148720

92-Vallitalea guaymasensis WP_113671481

$100[$ Clostridium grantii WP_073338521

Ilyobacter polytropus WP_013388647

_ Oceanotoga teriensis WP_109604717

- Prochlorococcus marimus WP_012007912.1

86
Marinisporobacter balticus WP_132242486
Peptoclostridium litorale WP_038260845
Petroclostriditum xylanilyticum WP_094548216 
Tba_ADH547

$\ldots \ldots \ldots \ldots \ldots$ MGEFSLKTRIVL. GEGSLSYIKSVAKKHSR $\ldots \ldots$. $\ldots$ VLIFSSKSMRVH $\ldots \ldots \ldots \ldots$ MEQLKTRIIE . GEGSIKALSREVRGYER . . . . . VIILSSSSMKRH $\ldots \ldots \ldots \ldots \ldots$ MEWLKTRIIE $\ldots$ GEGSISRLSREVKGHER $\ldots \ldots$ VLILASGSMKRH $\ldots \ldots \ldots \ldots \ldots$ MEWLKTRISE . GEDSLESIKDEAKDHER . . . . . VIILASGSMKRH ...... MLWESQIPINQIFEMRCKTTNYFGVGAINKFYDIAKDLKE. RGITKVILVTGRSSYKKO $\ldots \ldots \ldots$ MLWESCIPINQIFELRCRT IDYFGVGA INKFYDIAKDLKENRG ISRVILVTGKSSYKKO .......MVWESHVSINQVFEMRCKTTNYFGLCAIHKFNDIVRELKG.KGVDKVILVTGXSSYKKO ........ MVWESHVPINQVFELRCKTTDYFGLCAIHKFNGFVRELKG.KGVDRVILVTGSSSYKKO .......MLWESRL PINQVEELRCRT IDYFGVGAINKFYDIAKDLKENRDIDKVLIVTGKSSYKKO MAGQSFDLNFWHPSFFLPFLQNLCDSSNKNFGRKRLPELLER. HGLSG . . . . KPLMVTGRSSTKKT ....... MFEISIYLP. . TEIVFGPGK . . . LEML PKLVKK. HGLSG . . . . KPIIVTGRRSTKET $\ldots \ldots \ldots \ldots$ MASST . FYIPFVNEMGEGSLEKAIKDLNGSGE . . . KNALIVSDA FMNKS $\ldots \ldots \ldots \ldots$ MSSVTGFYIPPISFFGEGALEETADYIKNKDY . . . KKALIVTDPGIAAI I

SIMPKVR.EFQPDIIVAI ELLPKLREEFQPDLLVAI EFLPKVR.EFGPDLLVAY EFLPKVR.EFGPDLLIAM EAACMGR . EFGACAVIGI EAACMGK. EFGACAVIGI EAAEMGR. EFGACAVIGI EAAEMGR.EFGACAVIGI EAKEMGV.EFGACAVIGI EAAELAR . RENVDFVVGI EGAEIAR . KENVSFVVGI EGLKILK. DNNSDFVISI AGLKVLK. EQNSEIVVSI

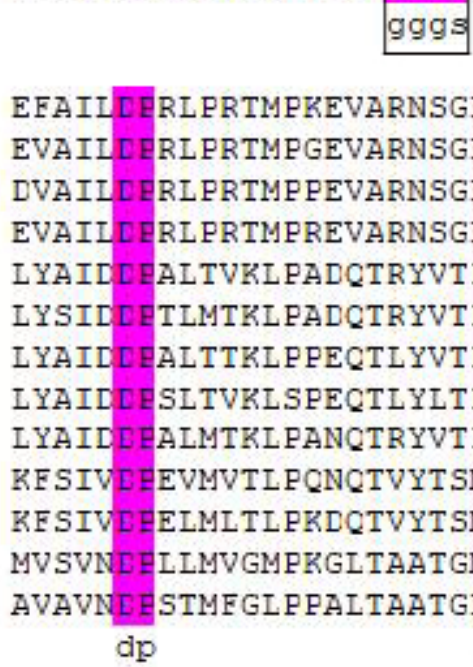
gggs ${ }^{\mathrm{d}} \mathrm{II}^{\mathrm{k}}$

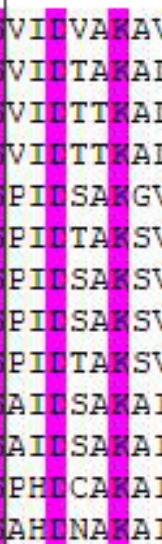

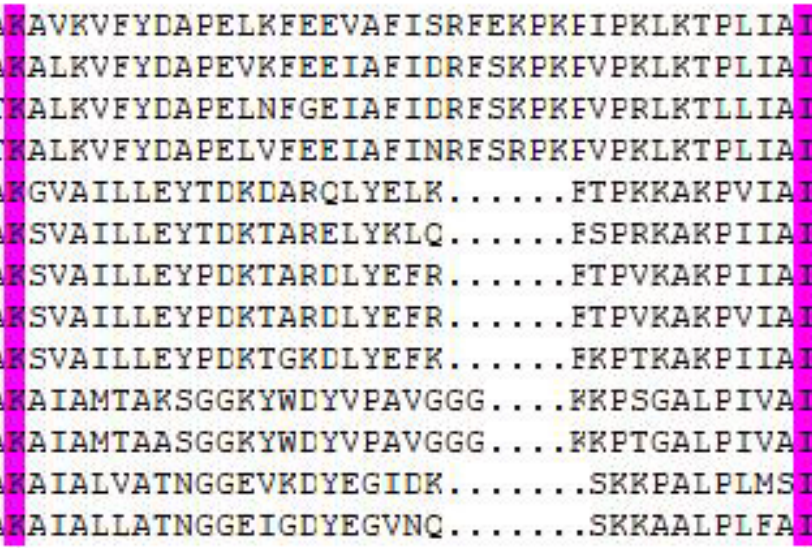

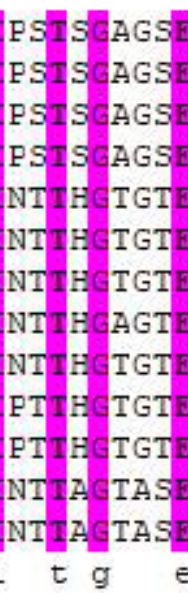

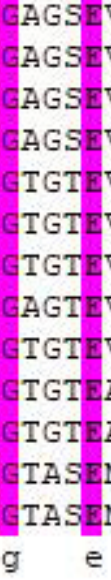
SAASVLKKGDIKYN . .LVSFEIRF SASSVLKKGEVKYN . IVSLEIAP VSGASVLKKGGVKYN . . IVTPEIR VSAASVLKKNGIKYN . . IVT PEIR VDREAVASILEKEYKEAIAYDCIYE VNRFAVASILEEEYKEA IAYDCIY VDREAVASIPEKEYKPAIAYDCIY VREAVATIPEKEYKPA IAYDCIY VDREAVASILEKEYKPA IAYDFIY ADPYAVITNPETKEKQGIGYDVLF ADPYAVITNPETKEKQGIGYDVLF MTRECIITDEVRHVKMA IVDRHVT MTRETIISNEEKK IKMAIIDNNVTP $\frac{\text { III }^{\mathrm{p}}}{*{ }^{*}}$

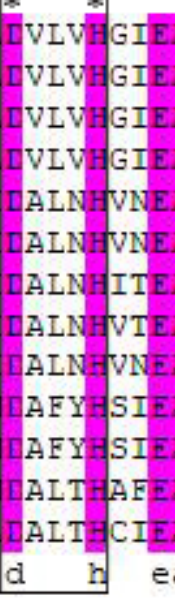
YTTTAAT
YTTKAAN
YTTKVAS
YTTKVAG
ATTKVAS
ATTKVAS
ATTKVAN
ATTKLAN
ATTKATN
FLNVRAO
FLNVRAN
YSSTAAT
YVSTASN
a

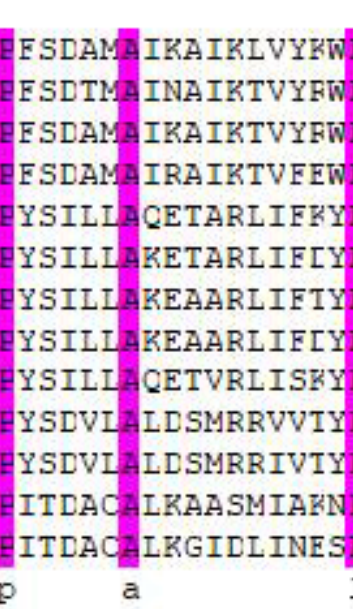
WI PLSVQG . . DEK
PLSVKG . . DEE
PLSVKG . . DEE
PKSVEG . . DPE
PEALNHPDNLC
PEAL IHPDNLC
PEALNHPDNLC
PEALKHPDNLC
PAALAHPENLC
PIAYENLQDLE
PLAYENLRNLE
KTACDNGKDME
S VAAYKDGKDKK
1 ARENVH
RARV
RARV
RARM
RYYL
RYYL
RYAL
RYAL
RYYL
RTQL
RTQL
REAM
RTDM
a YAATMAG
YAATMAG
YAATMAG
YAATMAG
YASAIAG
YA SAIAG
YA SAIAG
YASAIAG
YA SAIAG
WATEAG
WA STEAG
YACIAG
YAEYIAG
a a

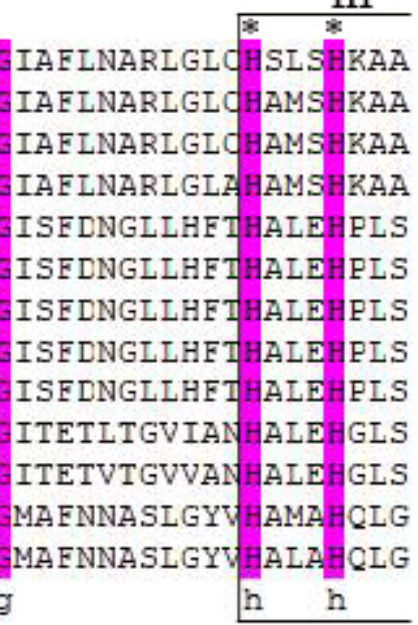

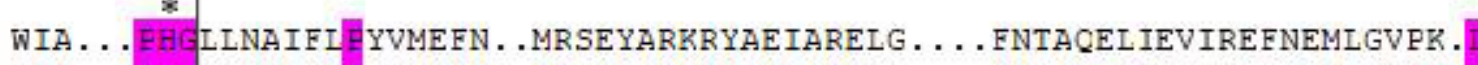
WIG . . EHGLINAIF I YYVMENA. ERSEYARKRYAE IAREIG . . . FNTAKDL IEVVKELNEMLGVPG. WIG . . FHGLLNAVEI YYVMEFNA . SKSDYARRRYAEIARELG . . . FOTAKDL IEVVKELNEMLGVPK. WVG. . . EHGLINAIF I YYVMEFNA. ERSEYARKRYAE IARELG . . . IRSAEEL IKAVRELNERLGVPK. AVKPEI EHG LGLAMLI AVIKHIYPATAPILAEVYRPLVPDAKG .VPG . EALKVPKAVEKWLFSIGITEK AVKPDI EHGLGLILI AVIKHIYPATARILAEIYRPLVPEVKG.VPG . EAELVAKKVEEWLFAIGITQK AVKPDI EHGLGLAMLI AAVIRCIYPATAKILAEVYRPLVPEAKG .VPG . EVELVPRRVEEWLFSIGITEK AVKPDFEHG IGLAMLI AAVIRHIYPATAKILAEVYRPLVPEAKG .VPG . EVELVPRRVEEWLFSIGITEK AVKPDI EHGLGLAMLI AVVKHIYPATAEILAEVYRPIAPEAKG . YPG . EAEFVDKR IECWLFSIGIKEK GFYPEV EHGLGLCILG YIFEYILDHAYERLAIVGREVFGVYES . NDRKAAELAVKKLRDFQSLFGVNKK GFYPEV EHGLGLCILG YIFEYILDYAYEKLAIVGREVFGVYEP.NDRKAAELA IKKLRDFQSLFGVNKK GYY. NL EHGVCNAVLI HVLAYNASVVAGRLRDVGVAMGLDIANLGDKEGAEATIQAVRDLAASIGIPAN

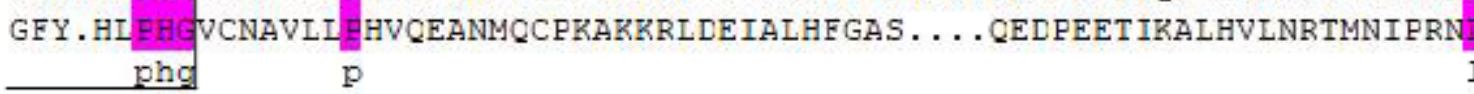

SELVSEEEFLSKLDEMSER. AYHDPLINF SELVDEEAFVSKVEEMANK. AYRDGLIPF GELVDEETFASKVEEMAEK. TYHDGLIAF SELVDEETFVERVEEMAER . AYRDGLIAF TDVGEGEDDVKKLAELAMTTPSLDLLLSL TDVGESEDDVKRLTELAMTTPSLNLLLSL ADVGFTEGDVDKLTQLAMTTPSLDLLLSM EDVGFSETDVNRLTELAMKTPSLNLLLSM TDVGEGEDDIDKLTKLAMETPGLDGLLAM RELGVKEEDIPKMAETAYR . .MMKGVIDV RELGVKEEDIPEMARTAYR . .MMKPVIEA TELGAKKEDVPLLADHALK . . . DACALT 1 KELGVKTEDFEILAEHAMH.... DACHLT

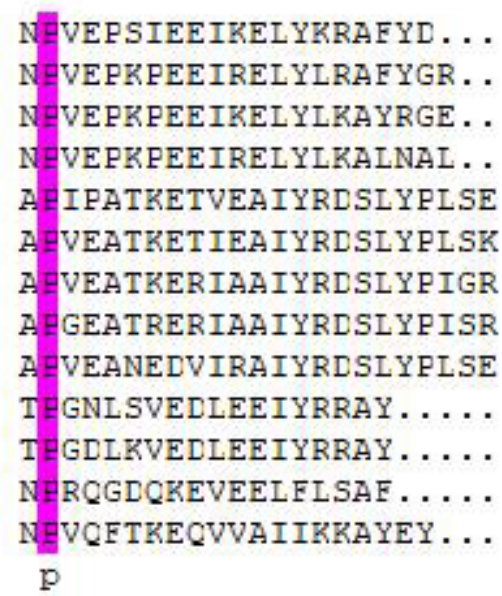

171

170

169

169

184

185

184

184

185

189

175

170

171

269

268

267

267

284

285

284

284

285

289

275

270 271

358

358

357

357

382

383

382

382

383

386

372

365

362

378 


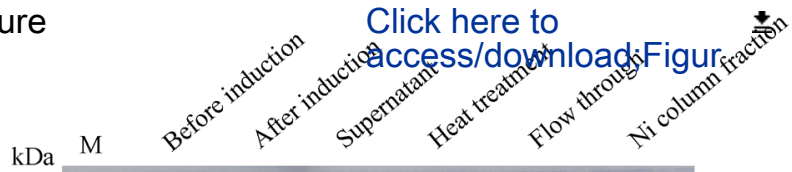

$75-$

50-

37-

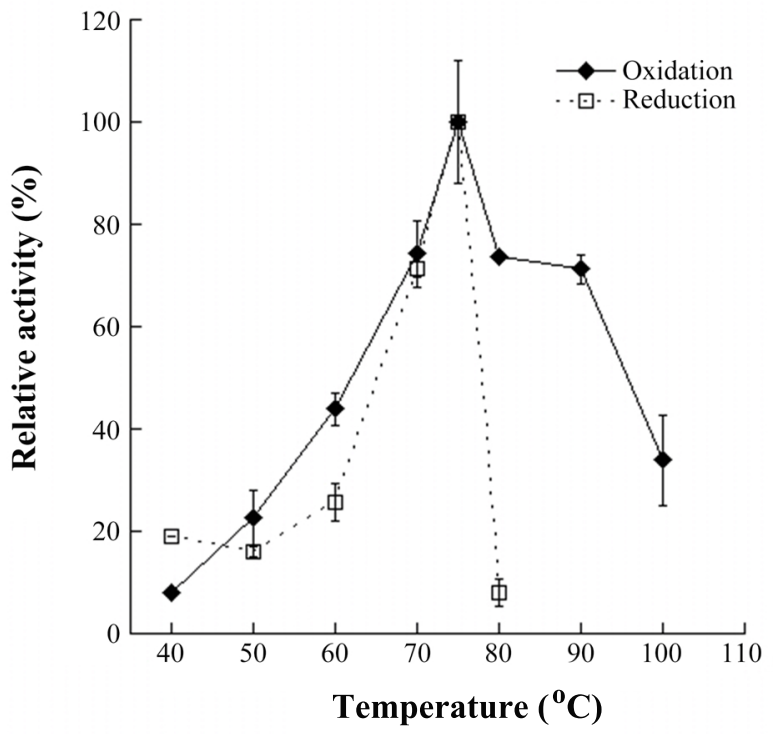


A Figure $_{120}$

อ 100

B. 80

60

40

20

0

0

CK
Click here to

access/download;Fig

B

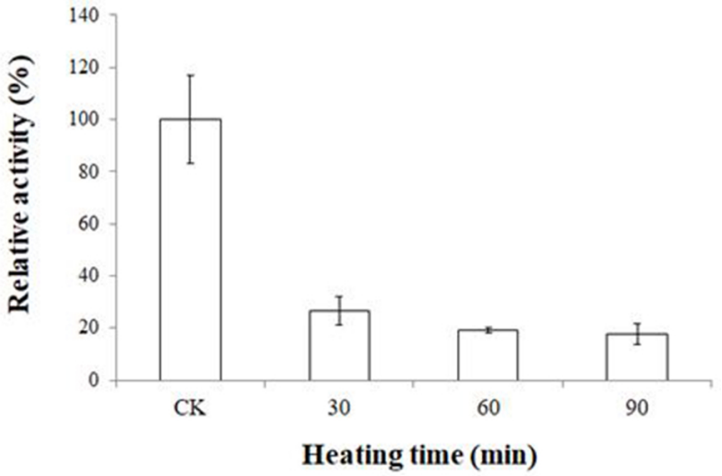




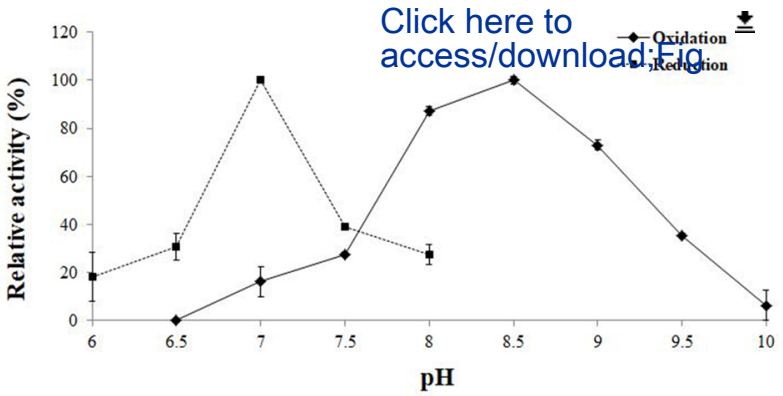

B

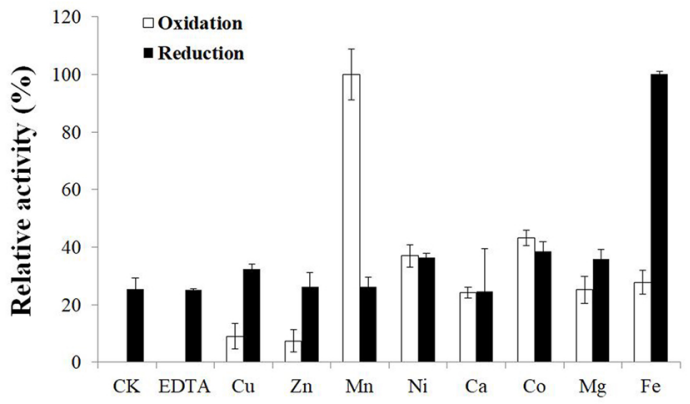


A

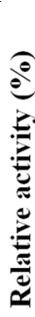

300

e 250

ㄹ. 200

150

100

50

50

0

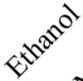

Click here to access/download;Fig

\section{r]}
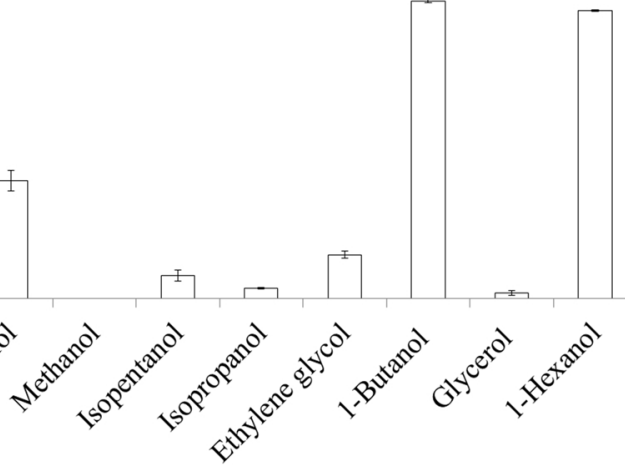

B

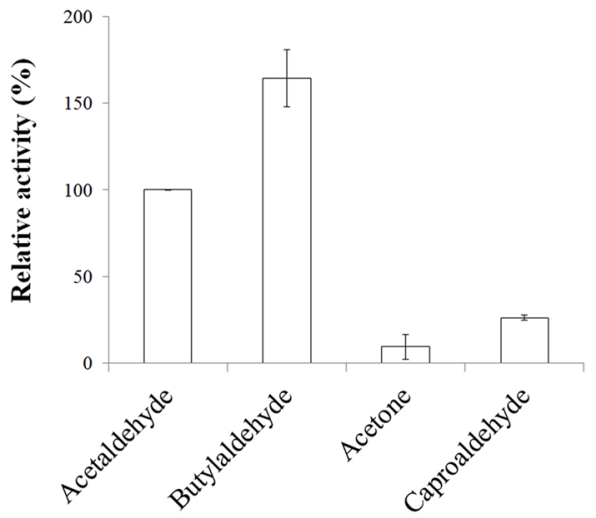


A

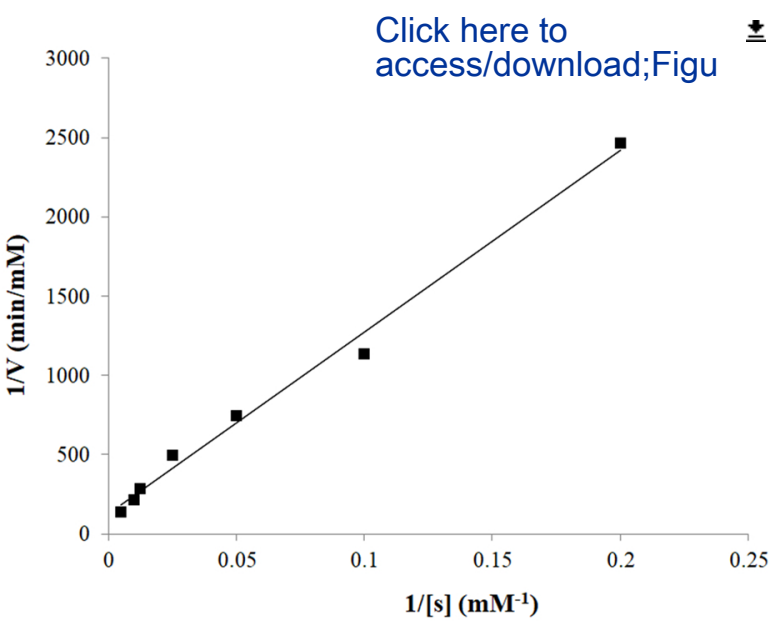

B

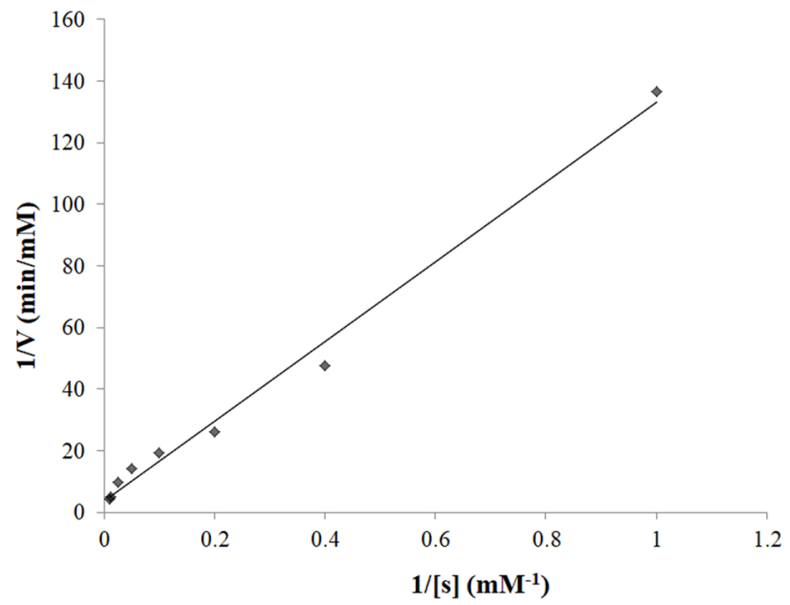




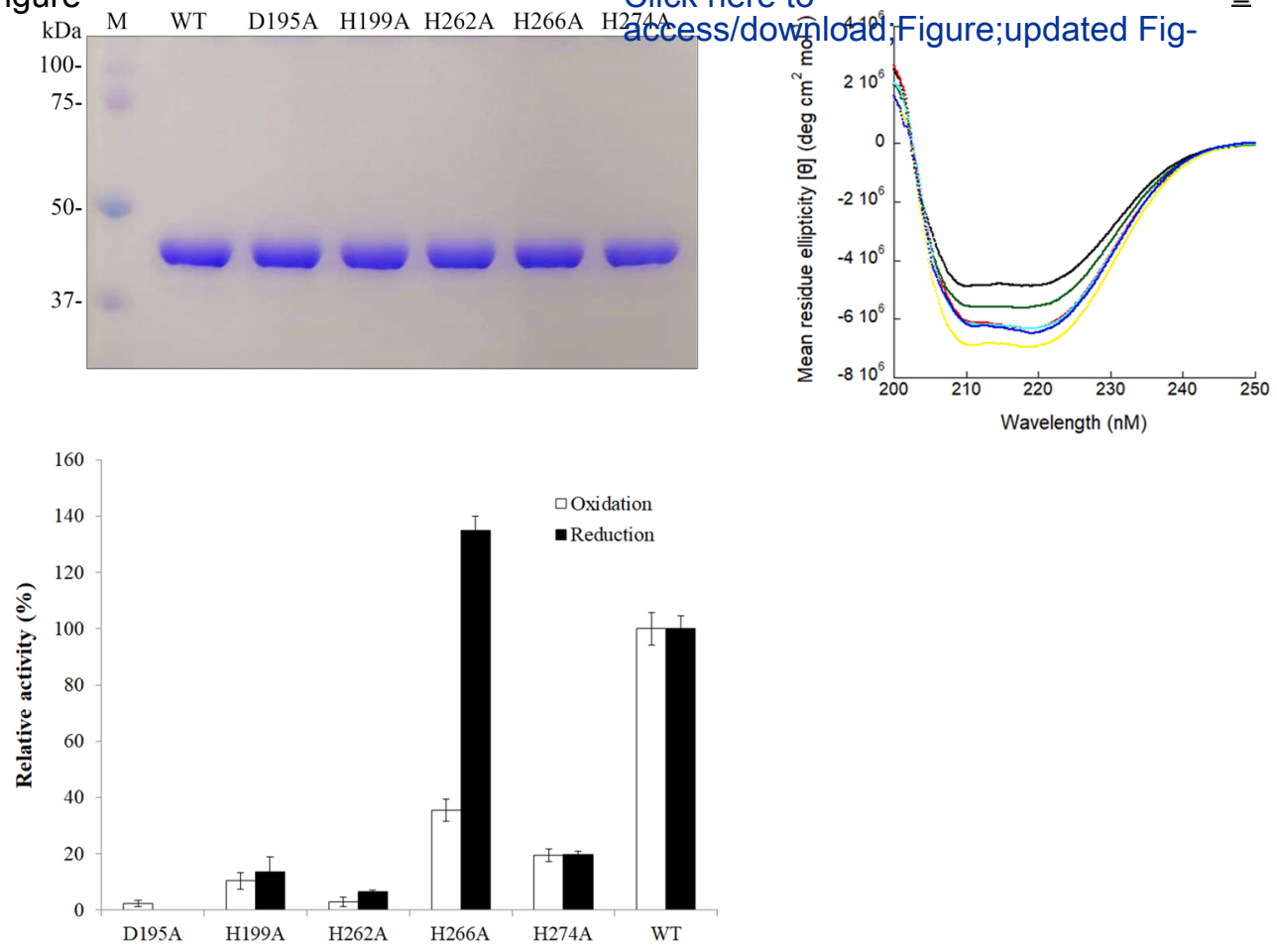

C 